\title{
Molecular probes and microarrays for the detection of toxic algae in the genera Dinophysis and Phalacroma (Dinophyta)
}

\author{
Bente Edvardsen • Simon M. Dittami • René Groben • \\ Sissel Brubak • Laura Escalera • Francisco Rodríguez • \\ Beatriz Reguera • Jixin Chen • Linda K. Medlin
}

Received: 31 August 2012 / Accepted: 3 December 2012 / Published online: 21 December 2012

(C) The Author(s) 2012. This article is published with open access at Springerlink.com

\begin{abstract}
Dinophysis and Phalacroma species containing diarrheic shellfish toxins and pectenotoxins occur in coastal temperate waters all year round and prevent the harvesting of mussels during several months each year in regions in Europe, Chile, Japan, and New Zealand. Toxicity varies among morphologically similar species, and a precise identification is needed for early warning systems. Molecular techniques using ribosomal DNA sequences offer a means to identify and detect precisely the potentially toxic species. We designed molecular probes targeting the $18 \mathrm{~S}$ rDNA at the family and genus levels for Dinophysis and Phalacroma and at the species level for Dinophysis acuminata, Dinophysis acuta, and Dinophysis norvegica, the most commonly occurring, potentially toxic species of these genera in Western European waters. Dot blot hybridizations with polymerase chain reaction (PCR)-amplified rDNA from 17 microalgae were used to demonstrate probe specificity. The probes were
\end{abstract}

Responsible editor: Robert Duran

Electronic supplementary material The online version of this article (doi:10.1007/s11356-012-1403-1) contains supplementary material, which is available to authorized users.

B. Edvardsen $(\bowtie) \cdot$ S. M. Dittami $\cdot$ S. Brubak

Marine Biology, Department of Biology, University of Oslo,

P.O. Box 1066, 0316 Oslo, Norway

e-mail: bente.edvardsen@bio.uio.no

R. Groben

VÖR-Marine Research Center at Breiðafjörður, Norðurtangi,

355 Ólafsvík, Iceland

L. Escalera $\cdot$ F. Rodríguez $\cdot$ B. Reguera

Centro Oceanográfico de Vigo, Instituto Español de Oceanografía,

Subida a Radiofaro 50,

36390 Vigo, Spain

J. Chen • L. K. Medlin

Marine Biological Association of the UK, Citadel Hill,

Plymouth PL1 2PB, UK modified along with other published fluorescence in situ hybridization and PCR probes and tested for a microarray platform within the MIDTAL project (http://www.midtal. com). The microarray was applied to field samples from Norway and Spain and compared to microscopic cell counts. These probes may be useful for early warning systems and monitoring and can also be used in population dynamic studies to distinguish species and life cycle stages, such as cysts, and their distribution in time and space.

Keywords Dot blot hybridization $\cdot$ Dinophysis $\cdot$ Harmful algal blooms $\cdot$ HABs $\cdot$ Microarray $\cdot$ Molecular probes . Phalacroma $\cdot$ Phylochips $\cdot$ Toxic algae

\section{Introduction}

Harmful marine microalgae cause large economic losses to the shellfish industry and fish farms through fish kills and through accumulation of toxins in shellfish above regulatory levels. They also prevent harvesting of wild mussels and other bivalves for several months per year and, in some cases, kill marine organisms and humans. Harmful algal blooms (HABs) may, in some cases, threaten public health and make the water unsuitable for bathing. Of the about 4,000 described microalgal species (Sournia et al. 1991), a few more than 100 have been found to be toxic, $70 \%$ of which belong to the class Dinophyceae (Sournia 1995). To date, 10 species of Dinophysis Ehrenberg and two species of Phalacroma Stein have been found unambiguously to contain diarrheic shellfish poisoning (DSP) toxins and/or pectenotoxins (Table 1; Moestrup et al. 2009 onwards; Reguera et al. 2012a, b). These toxins are the main cause of lengthy shellfish harvesting closures in Western Europe, from spring to autumn, in particular in Spain (Blanco et al. 1998), Portugal (Vale et al. 2008), France, Ireland (Jackson and 
Table 1 Potentially toxic species of the genera Dinophysis and Phalacroma

\begin{tabular}{|c|c|}
\hline Species & Reference \\
\hline $\begin{array}{l}\text { D. acuminata Claparède } \\
\text { et Lachmann }\end{array}$ & $\begin{array}{l}\text { Blanco et al. 2006; Fernández et al. 2001; } \\
\text { Hackett et al. 2009; Johansson et al. 1996; } \\
\text { Masselin et al. 1992; Miles et al. 2004; } \\
\text { Sato et al. } 1996\end{array}$ \\
\hline D. acuta Ehrenberg & $\begin{array}{l}\text { Lee et al. 1989; Fernández et al. 2001, } \\
\text { 2006; Fernández-Puente et al. 2004; } \\
\text { Johansson et al. 1996; Miles et al. 2004; } \\
\text { Pizarro et al. 2008b }\end{array}$ \\
\hline D. caudata Saville-Kent & Fernández et al. 2006; Marasigan et al. 2001 \\
\hline D. fortii Pavillard & $\begin{array}{l}\text { Lee et al. 1989; Sato et al. 1996; Suzuki } \\
\text { et al. } 2009\end{array}$ \\
\hline D. infundibula J.Schiller & Suzuki et al. 2009 \\
\hline D. miles Cleve & Marasigan et al. 2001 \\
\hline $\begin{array}{l}\text { D. norvegica Claparède } \\
\text { et Lachmann }\end{array}$ & Lee et al. 1989; Miles et al. 2004 \\
\hline D. ovum Schütt & Raho et al. 2008; Campbell et al. 2010 \\
\hline D. saccula Stein & Delgado et al. 1996; Giacobbe et al. 2000 \\
\hline D. tripos Gourret & Lee et al. 1989; Rodríguez et al. 2012 \\
\hline P. mitra F.Schütt & Lee et al. 1989 \\
\hline $\begin{array}{l}\text { P. rotundatum (Claparéde } \\
\text { \& Lachmann) Kofoid } \\
\text { \& Michener }\end{array}$ & Lee et al. 1989; González-Gil et al. 2011 \\
\hline
\end{tabular}

Silke 1995), Sweden (Lindahl et al. 2007), Norway (Aune et al. 1996; Dahl et al. 1996), and Iceland (http://www.hafro.is/ voktun/). The most common toxic species are Dinophysis acuminata Claparède \& Lachmann, Dinophysis acuta Ehrenberg, and Phalacroma rotundatum (Claparède \& Lachmann) Kofoid \& Michener. In addition, Dinophysis norvegica Claparède \& Lachmann is common and has been associated with DSP events in northwestern Europe (Godhe et al. 2002). The toxicity varies not only between, but also within, a species (Andersen et al. 1996; Dahl and Johannessen 2001; Marcaillou-Le Baut et al. 2005; Jørgensen and Andersen 2007; Lindahl et al. 2007; Pizarro et al. 2008a, 2009). Species determination is mainly based on cell form and size, but differentiation can be difficult: cells with an intermediate morphology are often observed that may represent different stages in polymorphic life cycles (Edvardsen et al. 2003 and references therein; Reguera and González-Gil 2001; Escalera and Reguera 2008). D. acuminata has long been assumed to be a species complex consisting of several similar species or "varieties" (Solum 1962; Edvardsen et al. 2003; Zingone et al. 1998) and this taxon has sometimes been used to label morphologically close species (D. acuminata, Dinophysis ovum Schütt, and Dinophysis saccula Stein) commonly referred to as the "D. acuminata species complex" (Raho et al. 2008). If the species complex embraces genetically different forms with different toxin contents, then this may explain the highly variable toxicity reported for $D$. acuminata, but other factors, such as strain variability, nutritional status, and stages in the population growth, may also be involved (Reguera et al. 2012a; Tong et al. 2011).

In addition, morphotypes in between two species often occur, e.g., D. acuta/D. norvegica, D. norvegica/D. acuminata, Dinophysis caudata Saville-Kent/Dinophysis tripos Gourret. The mechanism behind this is not yet clear, but hybridization between closely related species has been suggested (Edvardsen et al. 2003). This may possibly explain some of the variabilities in toxicity observed within a species. In Norwegian waters, D. acuta is considered the most toxic Dinophysis species with guideline values ("faregrense") of 200 cells $\mathrm{L}^{-1}$, whereas $D$. norvegica is considered only weakly toxic (Lee et al. 1989) with guideline values of 4,000 cells L ${ }^{-1}$ (http://algeinfo.imr.no). It is, therefore, important to have a precise method for identification. The delineation of $D$. acuminata is not clear. This species is highly variable in form, and many earlier described species have now been transferred to D. acuminata (Edvardsen et al. 2003; Moestrup et al. 2009 onwards) or, alternatively, some morphotypes identified as $D$. acuminata may have been misidentified and actually belong to life cycles of $D$. acuta, Dinophysis fortii Pavillard, or D. ovum.

Monitoring programs have been set up in several countries, in which water samples are examined regularly using light microscopy. A common problem is that the species of interest are difficult to identify and distinguish from morphologically similar species or strains with different toxic potential. Therefore, there is a need for species-specific or strain-specific probes, which can be used to detect only the cells of interest (Anderson 1995). The development of molecular tools, such as antibody probes and oligonucleotide probes for the detection of toxic algae, is steadily underway, but has come into more widespread use only for a limited number of species with probes that can only be used in limited geographical areas (Godhe et al. 2007; Miller and Scholin 1996; Simon et al. 1997; Scholin et al. 1997; Kavanagh et al. 2010).

Molecular probes detect molecules that are specific for the taxon (group of species, species, strains, etc.) of interest. They are short pieces of DNA (oligonucleotides) that bind to and detect specific RNA or DNA segments within the target cells but not in any nontarget organisms. The nuclear ribosomal RNA operon (rRNA genes and spacers) has been widely used to genetically characterize microorganisms and study their phylogenetic relationships. There is now a large number of DNA sequences available for the small subunit rRNA gene (SSU rDNA) for eukaryotic organisms in gene databases. The ARB-SILVA database (the database originally used in this study for probe design; Pruesse et al. 2007) contained 739,633 and 29,306 eukaryotic sequences in the SSU and LSU Ref (high-quality, long sequences) alignment, respectively, as of July 2012. Once the SSU rDNA sequence of a taxon and related taxa has been established, oligonucleotide 
probes that recognize only these taxa can be designed. The use of rDNA, with both conserved and highly variable regions, furthermore makes it possible to develop probes that are specific at various taxonomic levels, so-called hierarchical probes (e.g., Groben et al. 2004; Eller et al. 2007). These hierarchical probes provide an internal validation of the signals from natural samples (chapter 2 in Lewis et al. 2012).

Molecular probes can be coupled with a variety of recorder molecules (fluorescent, radioactive, chemiluminescent) and detection can be achieved using many different platforms (dot blot hybridization, fluorescence in situ hybridization (FISH), microarray). In typical dot blot hybridizations, polymerase chain reaction (PCR)-amplified samples are spotted onto a membrane and a digoxigenin (DIG)-labeled probe is added one at a time to hybridize to the PCR products, and this hybridization is visualized by chemiluminescence-exposing X-ray film. Additional probes can be added after the membrane is stripped. Microarrays improve the efficiency of the dot blot because a large number (in this study, over 160) of probes are spotted onto a glass slide to which fluorescently labeled RNA extracted from an environmental sample is hybridized. Hybridization between probes and target RNA of interest in the sample is detected by fluorescence of the labeled target by a laser in a microarray scanner.

In this study, oligonucleotide probes targeting the $18 \mathrm{~S}$ (SSU) rDNA at the family and genus levels for Dinophysis and Phalacroma and at the species level for D. acuminata, $D$. acuta, and D. norvegica were designed and applied to a dot blot hybridization assay to test probe specificity and a microarray assay to monitor spatial and temporal distribution of the species. Water samples collected at monitoring sites in Norway and Spain in the period 2010-2011 were applied to the microarrays and the signals were compared with microscopic cell counts. These probes provide rapid identification and detection of potentially toxic Dinophysis and Phalacroma species that can be incorporated into an early warning system of harmful algae.

\section{Material and methods}

Seawater sampling for microarrays and cell counts

Seawater samples were collected monthly from near-surface depths at two localities: (a) Outer Oslofjorden, Skagerrak, Southern Norway (station OF2, 59 $19^{\circ} \mathrm{N}, 10^{\circ} 69^{\prime} \mathrm{E}$, August 2010-June 2011) and (b) Ría de Pontevedra, Northwest Spain (station P2, 42 ${ }^{\circ} 8.22^{\prime} \mathrm{N}, 8^{\circ} 51.36^{\prime} \mathrm{W}$, April-July 2010). In Oslofjorden, $1 \mathrm{~L}$ water samples in three replicates were prefiltered through a $200-\mu \mathrm{m}$ sieve and filtered on nitrocellulose filters (3- $\mathrm{mm}$ pore size, $25 \mathrm{~mm}$ ). One milliliter TRI Reagent (Ambion, Applied Biosystems, Foster City,
CA, USA) and 500,000 cells of the green alga Dunaliella tertiolecta Butcher (UIO 226, CCAP 19/24, internal standard; chapter 5 in Lewis et al. 2012) were added to cryovials with the filters, and the vials were then frozen in liquid nitrogen and stored at $-80{ }^{\circ} \mathrm{C}$ until RNA extraction. In Ría de Pontevedra, Spain, seawater from 3 to $5 \mathrm{~m}$ depth was collected with a submersible pump during 5-10 min and passed through a set of superimposed framed meshes (100, 77 , and $20 \mu \mathrm{m}$ mesh size). The $20-77 \mu \mathrm{m}$ size fraction was selected as a Dinophysis field concentrate (to overcome the usual low density of this genus) and diluted with seawater into 5-L bottles so the plankton material was kept fresh and alive during transportation $(1 \mathrm{~h})$ to the laboratory. Five hundred milliliters of samples of this concentrate, each of these representing about $69 \mathrm{~L}$ of the original seawater, was filtered in triplicate as described previously.

Vegetative cells of $D$. acuminata, D. acuta, D. fortii, $D$. tripos, and $P$. rotundatum were picked by capillary isolation from the Ría de Pontevedra samples (the 20-77 $\mu \mathrm{m}$ size fraction Dinophysis field concentrate), and SSU rDNA was amplified from single cells by PCR and sequenced as previously described (Edvardsen et al. 2003). The rDNA fragments were used to test probe specificity on the microarray platform (see succeeding paragraphs).

For the Spanish and Norwegian water samples, $100 \mathrm{ml}$ water samples were preserved with $1 \mathrm{ml}$ Lugol's solution (Throndsen 1978), and cell counts of the potentially toxic species were performed using the Utermöhl method (Utermöhl 1958; Hasle 1978) according to standard procedures for the local monitoring programs. Subsamples of $10 \mathrm{ml}$ were sedimented for at least $6 \mathrm{~h}$, and all specimens in the whole bottom surface of the chamber were scanned and counted using a Nikon Eclipse TE 300 (Norway) or TE 200 (Spain) inverted microscope (phase contrast and $\times 100-400$ magnification).

\section{Cultures of Dinophysis}

Two Dinophysis species, D. acuminata (VGO1063; Oct 2009, St. B1, Ría de Vigo; $\left.42^{\circ} 21.40^{\prime} \mathrm{N} 8^{\circ} 46.42^{\prime} \mathrm{W}\right)$ and D. acuta (VGO1065; Oct 2010, St. P2, Ría de Pontevedra; $42^{\circ} 8.22^{\prime} \mathrm{N}, 8^{\circ} 51.36^{\prime} \mathrm{W}$ ), isolated from seawater samples collected in the Galician Rías were cultured in diluted (1/20) L1-Si medium (Guillard and Hargraves 1993) at $32 \mathrm{psu}$, 12:12-h light/dark cycle at $150 \mu \mathrm{mol}$ photons $\mathrm{m}^{2} \mathrm{~s}^{-1}$ irradiance, in $250 \mathrm{ml}$ flasks. Cultures of the ciliate Myrionecta rubra (Lohmann) Hamburger \& Buddenbrock (ANDA0711), fed on the cryptophyte Teleaulax amphioxeia (Conrad) Hill (AND-A0710), were added periodically as prey. Both ciliate and cryptophyte strains were isolated in 2007 from seawater samples collected in Huelva, Southwestern Spain, in the course of weekly sampling of the Andalusian Monitoring Programme (Huelva, SW Spain). 
Dinophysis cultures were actively growing and feeding on Myrionecta until sampling. To avoid contamination from Myrionecta or Teleaulax, Dinophysis cultures were gently rinsed with fresh medium through a 20 - $\mu$ m mesh immediately before filtration, and the resuspended material was inspected by light microscopy.

Design of oligonucleotide probes for dot blot hybridization

Eight probes for use in dot blot assays were designed targeting the small subunit (SSU, 18S) ribosomal DNA of Dinophysis and Phalacroma species (Table 2). The ARB (from 2005), now SILVA, database alignment was screened for signature positions for the four species, the two genera, and the family Dinophysiaceae using the "probe design" function of the program package ARB (Ludwig et al. 2004). The specificity of the potential probes was then tested in silico in ARB and by BLAST searches (last check in May 2012 revealed that the probe for $P$. rotundatum also recognizes other species of this genus and should now be regarded as a genus, not a species probe). The probes were examined for hairpin loops and primer dimer formation using the software Oligo 5 (http:// www.oligo.net). The probe's position in the RNA's secondary structure was checked within ARB. Available SSU rDNA sequences (greater than approximately $1,100 \mathrm{bp}$, as of May 2012) of members of the family Dinophysiaceae were downloaded from GenBank and aligned using MAFFT (v6.814b, default parameters; Katoh et al. 2005) in the software Geneious (Pro 5.5.6), and number of mismatches in the target site of the probes with target and nontarget organisms were examined for each probe by eye. A maximum likelihood phylogenetic tree was constructed based on this alignment, using PhyML at http://www.phylogeny.fr (Dereeper et al. 2008) with the $\mathrm{GTR}+\mathrm{G}+\mathrm{I}$ model and including gaps. Branch support was calculated using the Approximate Likelihood Ratio Test (aLRT). The resulting tree illustrates the clades and species for which probes were designed (Fig. 1). In vitro specificity of the dot blot probes was tested as described previously (Dittami et al. 2013a, b) and briefly in the succeeding section.

\section{Dot blot hybridizations}

Oligonucleotide probes, purchased from MWG (Martinsried, Germany) (Table 2), were labeled with DIG using a DIG Oligonucleotide 3' End Labelling Kit (Boehringer Mannheim, Mannheim, Germany, now Roche Diagnostics, Mannheim, Germany) according to the manufacturer's protocol. Their specificity was tested in vitro by dot blot hybridization with amplified SSU rDNA from 17 microalgal strains and 1 bacterium, blotted onto a membrane (Fig. 2). Amplified SSU rDNA was chosen instead of total genomic DNA to obtain higher and similar amounts of rDNA from each of the 17 species represented on the membrane. The amplified microalgal SSU rDNA was obtained by PCR using the general eukaryote primers $1 \mathrm{~F}$ and 1528R (Medlin et al. 1988), as described previously (Edvardsen et al. 2003). The SSU rDNA of the bacterium (strain PTB 7 isolated from a culture of Alexandrium tamarense (Lebour) Balech) was amplified as described by Groben et al. (2000). Membranes were prehybridized in hybridization buffer ( $5 \times$ saline-sodium citrate, $0.1 \% N$-lauroylsarcosine, $0.02 \%$ sodium dodecyl sulfate, and $1 \%$ blocking solution) at hybridization temperature for $6 \mathrm{~h}$ and subsequently incubated overnight with the hybridization buffer and DIG-labeled probes $\left(2.5 \mathrm{pmol} \mu \mathrm{L}^{-1}\right)$. Optimal hybridization temperatures and probe

Table 2 Oligonucleotide probes for dot blot hybridization (18-22 nt in length) for the detection of species of Dinophysis and Phalacroma and name of corresponding probes for microarray $(25 \mathrm{nt})$

\begin{tabular}{|c|c|c|c|c|c|c|}
\hline $\begin{array}{l}\text { Dot blot probe } \\
\text { name }\end{array}$ & $\begin{array}{l}\text { Corresponding microarray } \\
\text { probe name }\end{array}$ & Target taxa & $\begin{array}{l}\text { Target } \\
\text { region }\end{array}$ & $\begin{array}{l}\text { Temperature } \\
{\left[{ }^{\circ} \mathrm{C}\right]}\end{array}$ & $\begin{array}{l}\text { Probe } \\
\text { concentration }[\mathrm{ppb}]\end{array}$ & $\begin{array}{l}\text { Match with nontargets in } \\
\text { the marine environment }\end{array}$ \\
\hline DphyFL1 & DphyexacutaFS01_25 & $\begin{array}{l}\text { Dinophysiaceae (Dinophysis }+ \\
\text { Phalacroma) }\end{array}$ & SSU & 63 & 0.1 & Chromera velia $^{\mathrm{a}}$ \\
\hline DphyFL2 & DphyFS02_25 & $\begin{array}{c}\text { Dinophysiaceae (Dinophysis }+ \\
\text { Phalacroma }+ \text { Histioneis) }\end{array}$ & SSU & 57 & 0.1 & Chromera velia \\
\hline DphyGL1 & DphyGS01_25 & Dinophysis spp. & SSU & 54 & 0.01 & None \\
\hline DphyGL2 & DphyGS02_25 & Dinophysis spp. & SSU & 63 & 0.2 & None \\
\hline Dacum & DacumiS01_25 & Dinophysis acuminata & SSU & 65 & 0.01 & None \\
\hline Dacut & DacutaS01_25 & Dinophysis acuta & SSU & 54 & 0.05 & $\begin{array}{l}\text { Haliotis diversicolor }^{\mathrm{b}} \text {, } \\
\text { EU780640 of } D . \mathrm{cf} . \\
\text { acuminata }\end{array}$ \\
\hline Dnorv & DnorvS01_25 & Dinophysis norvegica & SSU & 54 & 0.01 & $\begin{array}{l}\text { See Table } 4+ \\
\text { Dinophysis miles }\end{array}$ \\
\hline Prot & ProtuS01_25 & Phalacroma spp. & SSU & 54 & 0.01 & None \\
\hline
\end{tabular}

Hybridization temperature and probe concentration to obtain specificity are given for each probe. The probe sequences are patent pending

${ }^{\text {a }}$ Alveolate isolated from the reef coral Montipora digitata

${ }^{\mathrm{b}}$ Gastropode 


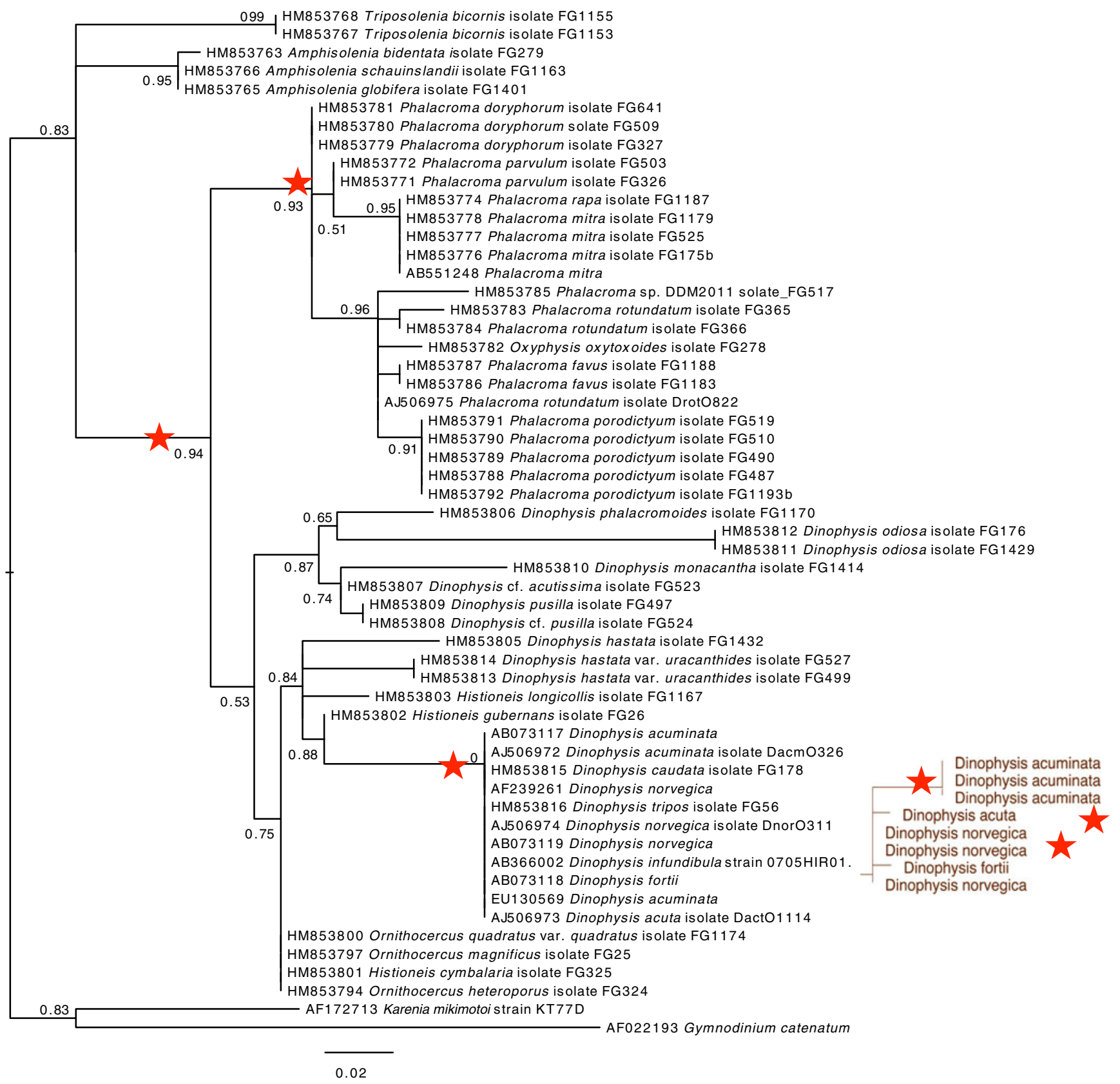

Fig. 1 Maximum likelihood tree (PhyML) based on SSU rDNA of members of Dinophysiales with aLRT as support values. Inset is a maximum parsimony tree from ARB to show branch lengths within the clade $D$. norvegica $+D$. acuminata, red stars denote the dot blot probe

concentrations were determined empirically for each probe and ranged from 54 to $65^{\circ} \mathrm{C}$ and from 0.01 to $0.2 \mathrm{ppb}$, respectively (Table 2). Detection was performed using the DIG Luminescent Detection Kit (Boehringer Mannheim, Mannheim, Germany) according to the manufacturer's protocol and as described previously (Dittami et al. 2013a, b). In short, the membranes were washed in a series of washing buffers, then incubated in a series of detection buffers followed by an incubation with CSPD (dilution 1:100). Finally, Kodak Biomax MR films for this clade. Probes for the clades, from top to bottom: clade 1: Prot; clade 2: DphyFL1, DphyFL2; clade 3: DphyGL1, DphyGL2; clade 4: Dacum; clade 5: Dacut; clade 6: Dnorv (for information on the probes, see Table 2)

were exposed to the plastic-sealed wet membranes for $90 \mathrm{~min}$ to record chemiluminescence. The general eukaryote-specific probe EUK 1209 (Lim et al. 1993) was used as a positive control.

Design of oligonucleotide probes for microarrays

A hierarchical, multispecies microarray for the detection of toxic marine algae targeting their SSU rRNA has been 
Fig. 2 Dot blot hybridization membranes spotted with SSU rDNA amplicons of 17 microalgae and 1 bacterium. The upper panel shows the position of algal/bacterial SSU rDNA amplicons on the membrane. The accession number for the sequences of these amplicons are from $A 1$ to C6: AJ506974, AJ5066975, AJ506972, AJ506973, Y16235, M14649, AF022199, M88521, AF022195, AF274277,

AF172712, AF022201, AF172713, AJ007276, X85390, AJ246271, X77476, and Y10915. The lower panel shows the results of hybridizations of different probes ( $a$ DphyGL1, $b$ DphyGL2, $c$ DphyFL1, $d$ DphyFL2, $e$ Dacum, $f$ Dacut, $g$ Dnorv, $h$ Prot, $i$ EUK 1209) to this membrane. Temperatures and probe concentrations were as described in Table 2

\begin{tabular}{|l|l|l|l|l|l|l|}
\hline & $\mathbf{1}$ & $\mathbf{2}$ & $\mathbf{3}$ & $\mathbf{4}$ & $\mathbf{5}$ & $\mathbf{6}$ \\
\hline A & $\begin{array}{l}\text { Dinophysis } \\
\text { norvegica }\end{array}$ & $\begin{array}{l}\text { Phalacroma } \\
\text { rotundatum }\end{array}$ & $\begin{array}{l}\text { Dinophysis } \\
\text { acuminata }\end{array}$ & $\begin{array}{l}\text { Dinophysis } \\
\text { acuta }\end{array}$ & $\begin{array}{l}\text { Prorocentrum } \\
\text { lima }\end{array}$ & $\begin{array}{l}\text { Prorocentrum } \\
\text { micans }\end{array}$ \\
\hline B & $\begin{array}{l}\text { Lepidodinium } \\
\text { viride }\end{array}$ & $\begin{array}{l}\text { Symbiodinium } \\
\text { microadriaticum }\end{array}$ & $\begin{array}{l}\text { Karenia } \\
\text { mikimotoi 1 }\end{array}$ & $\begin{array}{l}\text { Scrippsiella } \\
\text { trochoidea }\end{array}$ & $\begin{array}{l}\text { Karlodinium } \\
\text { micrum }\end{array}$ & $\begin{array}{l}\text { Pentapharsodinium } \\
\text { thyrrhenicum }\end{array}$ \\
\hline $\begin{array}{l}\text { C } \\
\text { Karenia } \\
\text { mikimotoi 2 }\end{array}$ & Chilomonas sp. & $\begin{array}{l}\text { Chaetoceros } \\
\text { sp. }\end{array}$ & $\begin{array}{l}\text { Prymnesium } \\
\text { kappa }\end{array}$ & $\begin{array}{l}\text { Phaeocystis } \\
\text { globosa }\end{array}$ & PTB 7 (Prokaryota) \\
\hline
\end{tabular}

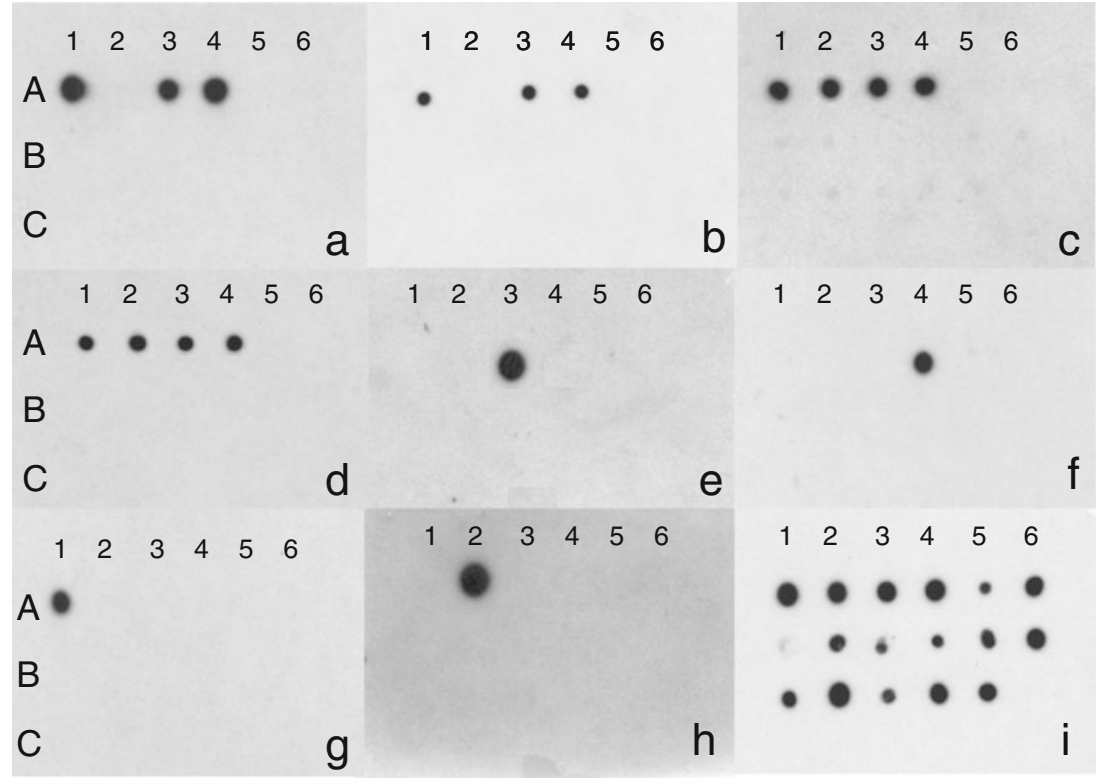

developed within the European FP7 program project Microarrays for the Detection of Toxic Algae (MIDTAL; http:// www.midtal.com). Within the project consortium, seven partners designed probes for different microalgal taxa for this chip and then tested them with cultures and field material. The microarray included probes targeting members of Dinophysis and Phalacroma at different taxonomic levels: two probes targeting Eukaryota (EukS_328_25 and EukS 1209_25), two targeting the division Dinophyta (DinoB_25 and DinoE12_25), three targeting the family Dinophysiaceae or the Dinophysis and Phalacroma genera (DphyexacutaFS01_25, DphyFS02_25, and DphyGS03_25), four targeting a clade embracing the phototrophic members of Dinophysis (Dinophysis sensu stricto; DphyGD02 25, DphyGS01_25, DphyGS02_25, and DphyGS04_25) and two targeting clades within this Dinophysis clade (DphyGD01_25 and DacumiD02 25), in addition to four "species-specific" probes (DacutaD02 25, DacumiS01 25, DacutaS01 25, and DnorvS01 25), and finally, one targeting the genus Phalacroma (ProtuS01 25), as shown in Table 3 (but see match with nontarget taxa in Table 3). The first microarray probes tested were the dot blot SSU rDNA probes developed previously and the LSU rDNA PCR probes designed by Guillou et al. (2002). All probes were then extended to 25 nucleotides (nt) length to meet the standards set for the microarray platform. Two new probes were designed with the ARB program at genus (DphyGS04_25) and family (DphyGS03_25) levels for the microarray platform (Table 3). Generation 3 consisted of all probes that were retained after optimization during the specificity testing of generation 2 . The nucleotide sequences of the probes were not changed from generation 2 to generation 3 and are patent pending. A complete list of all probes on the generation 3 chip can be found in Supplementary Table S1. A comercial kit containing all components for the hybridization and generation 3 microarrays will soon be available from Kreatech (Amsterdam, The Netherlands), and a complete and detailed protocol for a successful hydridization from sampling to analysis is now available from Koeltz (Lewis et al. 2012).

\section{Microarray hybridizations}

Probes for the MIDTAL microarray were synthesized with a 5'-amino-C6-linker by Thermo Scientific (Waltham, MA, USA), and a minimum of four replicate spots were spotted on epoxy-coated Nexterion E slides (Schott, Mainz, Germany) by Scienion (http://www.scienion.de) for generation 3 and by Jixin Chen with a pin printer VersArray ChipWriter 
Table 3 Information on oligonucleotide probes for microarrays (on generation 3) for the detection of species of Dinophysis and Phalacroma

\begin{tabular}{|c|c|c|c|c|}
\hline Probe name & Target taxa & Target region & Reference & Match with nontarget \\
\hline EukS_328_25 & Eukaryota & SSU & Moon-van der Staay et al. 2000 & See original reference \\
\hline EukS_1209_25 & Eukaryota & SSU & Lim et al. 1993 & See original reference \\
\hline DinoB_25 & Dinophyta + Apicomplexa & SSU & $=$ Dino 01 in John et al. 2003 & See original reference \\
\hline DinoE12_25 & Dinophyta + Apicomplexa & SSU & Metfies and Medlin 2008 & See original reference \\
\hline DphyexacutaFS01_25 & Dinophysiaceae (Dinophysis + Phalacroma) & SSU & This study & Chromera velia \\
\hline DphyFS02_25 & $\begin{array}{l}\text { Dinophysiaceae (Dinophysis }+ \\
\text { Phalacroma }+ \text { Histioneis sp.) }\end{array}$ & SSU & This study & Chromera velia \\
\hline DphyGS03_25 & Dinophysiaceae (Dinophysis + Phalacroma) & SSU & This study & Chromera velia \\
\hline DphyGD02_25 & Dinophysis spp. & LSU & Guillou et al. 2002 & None \\
\hline DphyGS01_25 & Dinophysis spp. & SSU & This study & None \\
\hline DphyGS02_25 & Dinophysis spp. & SSU & This study & None \\
\hline DphyGS04_25 & Dinophysis spp. & SSU & This study & None \\
\hline DphyGD01_25 & $\begin{array}{l}\text { D. acuminata, } D . \text { dens, } D . \text { fortii, } D \text {. } \\
\text { norvegica, } D . \text { ovum, } D \text {. saccula }\end{array}$ & LSU & Guillou et al. 2002 & None \\
\hline DacumiD02_25 & $\begin{array}{l}\text { D. acuminata, D. acuta, D. dens, D. fortii, } \\
\text { D. norvegica, D. ovum, D. saccula }\end{array}$ & LSU & Guillou et al. 2002 & None \\
\hline DacutaD02_25 & Dinophysis acuta $+D$. fortii & LSU & Guillou et al. 2002 & $\begin{array}{l}\text { D. infundibula, D. truncata, } \\
\text { D. schroederi }\end{array}$ \\
\hline DacumiS01_25 & Dinophysis acuminata & SSU & This study & None \\
\hline DacutaS01_25 & Dinophysis acuta & SSU & This study & None \\
\hline DnorvS01_25 & Dinophysis norvegica & SSU & This study & See Table $4+D$. miles \\
\hline ProtuS01_25 & Phalacroma spp. & SSU & This study & None \\
\hline
\end{tabular}

Hybridization temperature for the microarray was $65{ }^{\circ} \mathrm{C}$

Pro (Bio-Rad Laboratories GmbH, Munich, Germany) and split pins (Point Technologies, Inc., Lyons, CO, USA) for generation 2 arrays. Microarray hybridizations for generation 3 chips were performed according to the manual developed within MIDTAL (Lewis et al. 2012) and for generation 2 according to the protocol described by Kegel et al. (2013). Total RNA was extracted from the field samples using TRI Reagent according to the manufacturer's RNA protocol with two additional steps: the filters with cells were agitated with $300-\mu \mathrm{m}$ glass beads in a Precellys 24 homogenizer (two times, $15 \mathrm{~s}$ at $6,000 \mathrm{rpm}$ ). Secondly, after the final step, RNA was cleaned up once more using RNeasy MinElute Cleanup Kit (Qiagen, Hilden, Germany) following the vendor's recommendations. One microgram of this RNA was used for further processing. Because field samples from Vigo were not spiked with Dunaliella cells, 20 ng of Dunaliella RNA were added to the 1- $\mu$ g RNA aliquots as internal standard. Samples were then labeled using the Platinum Bright 647 Nucleic Acid Labeling Kit (Kreatech Diagnostics, Amsterdam, Netherlands) according to the manufacturer's instructions. Hybridizations were performed in a wet chamber for $60 \mathrm{~min}$ at $65{ }^{\circ} \mathrm{C}$ according to Lewis et al. (2012). Microarray chips were scanned using an Axon GenePix 4000B Scanner and Genepix Pro 6.0 (Molecular Devices, Sunnyvale, CA, USA). Integrated signals of replicate spots were averaged after subtraction of the local background and normalized by dividing the average signal of each probe by the signal for a probe targeting the $D$. tertiolecta SSU rDNA (DUNGS02_25). In the case of samples from Spain, normalized signals were corrected to account for the fact that only a proportion of the sample was hybridized. This was done by multiplication with a correction factor $f(f=$ total quantity of RNA extracted/quantity of RNA used for hybridization). For the Oslofjorden samples, this correction was not necessary, as the internal standard (Dunaliella cells) was added at the sampling stage to the entire sample collected on a filter. Calculations were performed using the GPR Analyzer software developed within the MIDTAL project and are described in detail by Dittami and Edvardsen (2013).

Specificity and calibration of microarray probes

The probes were tested for their specificity on the microarray platform in two ways. First, picked single cells of D. acuminata, D. acuta, D. fortii, D. tripos, and P. rotundatum were used as template in the PCR amplification of the SSU rDNA as described by Edvardsen et al. (2003). The specificity of the microarray probes was tested under different stringency conditions (washing temperature) using the amplified SSU rDNA fragment at concentrations similar to those used when hybridizing total RNA in the assay (generation 3 microarray). 
Second, in order to calibrate the microarrays, RNA was extracted from cultures of D. acuminata strain VGO1063 and D. acuta strain VGO1065. Prior to RNA extraction, samples of the cultures were fixed with Lugol's solution and cell concentrations determined following the same procedure as for field samples. Mean cellular RNA contents were calculated from triplicate cultures (Blanco et al., submitted; Taylor et al. submitted), and maximum and minimum RNA contents as well as the corresponding standard deviations are reported here. Different quantities of RNA (from 20 to $1,500 \mathrm{ng}$ in $D$. acuminata and from 20 to $400 \mathrm{ng}$ in D. acuta, corresponding to $400-30,000$ and $240-4,800$ cells, respectively, based on a mean RNA amount per cell of 0.050 and $0.083 \mathrm{ng}$ for $D$. acuminata and $D$. acuta) were hybridized to elaborate a calibration curve for each species and to check the specificity of microarray probes using total RNA (generation 3 microarray). Twenty nanograms of $D$. tertiolecta RNA (strain UIO226/CCAP 19/6B) was included as internal control in all hybridization reactions, and signals were normalized against the DUNGS02_25 probe (Lewis et al. 2012). These calibration curves were then used to infer cell numbers from microarray signals obtained with field samples.

\section{Results}

Dot blot hybridizations

We designed eight oligonucleotide probes, 18-22 nt in length, for the dot blot hybridization assay targeting the SSU rDNA region. The two probes DphyFL1 and DphyFL2 targeting the group Dinophysis + Phalacroma and possibly targeting the family Dinophysiaceae (DphyFL2 also shows $100 \%$ match to sequences of Histioneis spp.; there are no available sequences in the target site of DphyFL1 of other genera in the family than Dinophysis and Phalacroma), two for the phototrophic members of the genus Dinophysis sensu stricto (DphyGL1 and DphyGL2), one for the genus Phalacroma (Prot), and one species-specific probe each for $D$. acuminata, D. acuta, and D. norvegica (Dacum, Dacut, and Dnorv) were also designed (Table 2). The clades for which we have designed probes are marked on the ML phylogenetic tree in Fig. 1. The number of mismatches in the probes to SSU rDNA of target and nontarget taxa within the family Dinophysiaceae is shown in Table 4. As a rule, the probes matched perfectly $(100 \%)$ with target sites in
Table 4 Number of mismatches between Dinophysis and Phalacroma dot blot hybridization probes and SSU rDNA target and nontarget organisms within the Dinophysiaceae nd no sequence data available

a'Zero mismatches to AJ506972, EU130569, and FJ869120, but three to $\mathrm{AB} 073117$

\begin{tabular}{|c|c|c|c|c|c|c|c|c|}
\hline Species Probe & DphyFL1 & DphyFL2 & DphyGL1 & DphyGL2 & Dacum & Dacut & Dnorv & Prot \\
\hline D. acuminata & 0 & 0 & 0 & 0 & $0^{\mathrm{a}}$ & 3 & 2 & $\geq 1$ \\
\hline D. acuta & 0 & 0 & 0 & 1 & 3 & 0 & 3 & 4 \\
\hline D. norvegica & 0 & 0 & 0 & 0 & 1 & 3 & 0 & 2 \\
\hline P. rotundatum & 0 & 0 & 3 & 6 & 2 & 3 & 1 & 0 \\
\hline D. caudata & 0 & 0 & 0 & 1 & 1 & 3 & 0 & 2 \\
\hline D. fortii & 0 & 0 & 0 & 1 & 4 & 1 & 4 & 5 \\
\hline D. infundibula & 0 & 0 & 0 & 1 & 5 & 2 & 5 & 5 \\
\hline D. odiosa & 1 & 1 & 5 & 6 & 3 & 5 & 2 & 0 \\
\hline D. tripos & nd & nd & 0 & nd & 1 & 3 & 0 & 2 \\
\hline D. hastata & nd & nd & 3 & nd & 4 & 3 & 2 & 2 \\
\hline D. phalacromides & nd & nd & 3 & nd & 8 & 8 & 3 & 2 \\
\hline D. acutissima & nd & nd & 4 & nd & 2 & 3 & 0 & 1 \\
\hline D. pusilla & nd & nd & 4 & nd & 2 & 3 & 0 & 1 \\
\hline D. monacantha & nd & nd & 3 & nd & 9 & 7 & 6 & 4 \\
\hline P. doryphorum & nd & nd & 3 & nd & 3 & 3 & 1 & 0 \\
\hline P. favus & 0 & 0 & 3 & 6 & $\geq 2$ & $\geq 3$ & 1 & 0 \\
\hline P. mitra & 0 & 0 & 3 & 6 & 3 & $\geq 3$ & 1 & 0 \\
\hline P. porodictyum & 1 & 1 & 2 & nd & 2 & 3 & 1 & 0 \\
\hline P. parvulum & nd & nd & 2 & nd & 2 & 3 & 1 & 0 \\
\hline P. rapa & nd & nd & 3 & nd & 5 & 5 & 1 & 0 \\
\hline $\begin{array}{l}\text { Ornithocercus } \\
\text { spp. }\end{array}$ & nd & nd & 2 & nd & 2 & 3 & 0 & 1 \\
\hline Histioneis spp. & nd & 0 & $\geq 2$ & nd & 2 & 3 & $0-1$ & 2 \\
\hline $\begin{array}{l}\text { Amphisolenia } \\
\text { spp. }\end{array}$ & nd & nd & $\geq 3$ & nd & $\geq 2$ & $\geq 4$ & 4 & $\geq 2$ \\
\hline $\begin{array}{l}\text { Triposolenia } \\
\text { spp. }\end{array}$ & nd & nd & 6 & nd & $\geq 4$ & $\geq 6$ & 8 & 3 \\
\hline
\end{tabular}


the target organisms. Exceptions were the two probes targeting Dinophysis + Phalacroma and possibly the family Dinophysiaceae, which both had one mismatch with the species Dinophysis odiosa (Pavillard) Tai \& Skogsberg (accession numbers HM853811 and HM853812) and Phalacroma porodictyum Stein (accession numbers HM853788HM853792). However, these two heterotrophic species are not on the IOC-UNESCO reference list of toxic Dinophysis/ Phalacroma species and have, thus, never been associated with toxic shellfish. The probe DphyGL1 had $100 \%$ match with all phototrophic members of Dinophysis where SSU rDNA sequences are available (see Fig. 1; Table 4), but the "genus probe" DphyGL2 had one mismatch with D. acuta, D. caudata, D. fortii, and D. infundibula (Table 4). Another exception was the probe for D. acuminata (Dacum), where the sequence $\mathrm{AB} 073117$ of $D$. acuminata differed in three positions with the probe and with all other available sequences of this species in the target region (AJ506972, EU130569, and FJ869120), and it is likely that this strain is misidentified or these are PCR or sequencing errors. As a rule, the probes had at least one mismatch to nontarget cooccurring (marine plankton) and phylogenetically related taxa (Table 4). One mismatch centrally located in the probe has previously been proven to be sufficient to obtain specificity (John et al. 2005), and with the use of a competitor probe to remove the one mismatch target from the reaction, single base mismatches can often easily be detected. The probe Dnorv also has $100 \%$ match with some additional species (D. tripos, D. caudata, Dinophysis acutissima, Dinophysis pusilla, Dinophysis miles, Ornithocercus spp., and Histioneis spp.). However, in Scandinavian waters where $D$. norvegica is mainly distributed, these species have never been recorded or are rare (Johnsen and Lømsland 2012). D. caudata and D. tripos have been observed in low numbers occasionally in Norwegian waters (Johnsen and Lømsland 2012). In contrast, D. norvegica was the most abundant and most frequently observed Dinophysis species in outer Oslofjorden in this study (see below).

All probes were tested in vitro in the dot blot hybridization assays using PCR-amplified SSU rDNA fragments of target and nontarget species fixed to a membrane. The nontarget species represented ecologically relevant or phylogenetically related algal species (Fig. 2, upper panel). Dot blot hybridizations demonstrated that the probes were specific for the target organism or group (Fig. 2, lower panel $\mathrm{a}-\mathrm{h}$ ). Hybridization temperatures and probe concentrations were adjusted to obtain specificity with only one mismatch or more to the nontarget rDNA (Tables 2 and 4). At these concentrations, one nucleotide mismatch in nontarget organisms was sufficient, but by increasing the probe concentrations, we could modify the specificity so that the probes also hybridized rDNA with one mismatch (Table 2; Fig. 2). At the probe concentration of $0.01 \mathrm{ppb}$, the probe DphyGL2 only hybridized to $D$. acuminata and $D$. norvegica, but at $0.2 \mathrm{ppb}$, it also hybridized to D. acuta (Fig. 2, lower panel b), which had $1 \mathrm{bp}$ mismatch with the probe. The specificity to rDNA of $D$. caudata, D. fortii, and D. infundibula was not tested in vitro, but these had the same mismatch to the probe as $D$. acuta and can be assumed to also hybridize to probe DphyGL2 at a higher probe concentration $(0.2 \mathrm{ppb})$. This probe had six mismatches to the Phalacroma species and $D$. odiosa and can thus be used as a phototrophic Dinophysisspecific probe (clade 3 in Fig. 1), by modifying probe concentrations. The eukaryote probe, EUK 1209 (positive control), hybridized to all eukaryotic algal samples spotted on the nylon membranes (Fig 2, lower panel i). The SSU rDNA amplicon of the bacterium PTB 7, isolated from a culture of the dinoflagellate $A$. tamarense (Groben et al. 2000), served as a negative control, and none of the probes hybridized to this rDNA further verifying their specificity.

\section{Microarrays}

\section{Probes}

We adapted the probes developed for dot blot hybridization for use on a microarray platform for the detection of toxic algae, developed in the MIDTAL project. This entailed primarily lengthening the probes to $25 \mathrm{nt}$. We used total RNA instead of total DNA to omit the PCR amplification step to obtain a semiquantitative assay. Ribosomal RNA is present in relatively higher amounts in the cell compared to rDNA, and in addition, this also enabled us to add probes from different regions on the microarray (SSU and LSU rRNA). To complement the eight probes designed in this study for dot blot hybridization, we included the four LSU rDNA PCR probes originally designed by Guillou et al. (2002) and two higher-level probes for dinoflagellates (DinoB_25 and DinoE12_25; Table 3). We also modified one of the original dot blot probes (DphyFL01) by shifting the target region some positions to obtain a stronger signal, resulting in the probe DphyexacutaFS01_25 (only on generation 3), and designed two new probes, DphyGS03_25 and DphyGS04_25 in ARB (Table 3). At a length of $25 \mathrm{nt}$, set as the standard within the MIDTAL consortium, we were able to use the same hybridization temperature $\left(65^{\circ} \mathrm{C}\right)$ for all probes and prevented further close matches with nontargets, especially those with a single base pair mismatch and avoided the need for the competitor probe. In Figs. 3 and S1, there are several examples of the signal intensity for the version of the probe with a length of 18-22 and $25 \mathrm{nt}$, with the shorter version producing weak or no signals; compare Dacum with DacumiS02_25, Dacut with DacutaS02_25, and Dnorv with DnorvS01_25. 


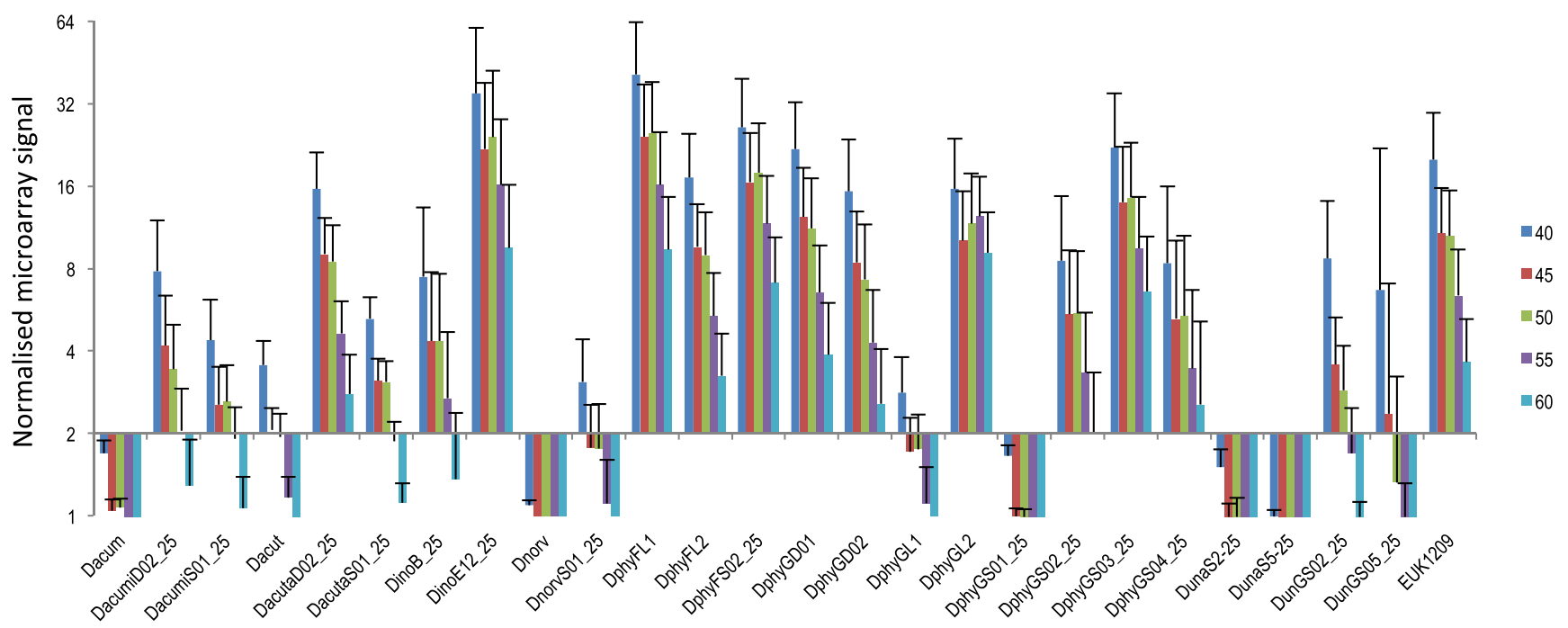

Fig. 3 Normalized microarray $\mathrm{S} / \mathrm{N}$ ratios ( $y$-axis) under increasing washing temperatures $\left(40-60{ }^{\circ} \mathrm{C}\right.$, indicated by the color of the bar) from microarray generation 2 probes hybridized to ribosomal DNA fragments of $D$. acuta. An $\mathrm{S} / \mathrm{N}$ ratio of 2 was considered as cutoff for a

\section{Specificity of microarray probes}

The specificity of the microarray probes and some of the shorter dot blot probes was tested on the microarray platform generation 2 (for the probe list, see Table 5) using rDNA fragments obtained by PCR of single cells of $D$. acuminata, D. acuta, D. fortii, D. tripos, and $P$. rotundatum. We tested different washing temperatures $(40,45,50,55$, and $60{ }^{\circ} \mathrm{C}$ ) to obtain different stringency conditions (a high washing temperature gives higher stringency) (Figs. 3 and S1a-d). All family-level (or Dinophysis + Phalaocroma) probes (DphyFL1, DphyFS02_25, DphyFL2, and DphyGS03_25) hybridized to all tested Dinophysis and Phalacroma samples, although weakly for the two first probes. The genus-level probes DphyGD01, DphyGD02, DphyGL2, DphyGS02_25, and DphyGS04_25 hybridized to all Dinophysis rDNA samples, and not to rDNA of $P$. rotundatum (Table 5), verifying their specificity to the phototrophic members of Dinophysis. The generic-level probe DphyGS01_25 did not work at any washing temperature, and the corresponding 18-nt probe DphyGL1 only hybridized to rDNA of D. acuminata and D. acuta at the washing temperature of $40^{\circ} \mathrm{C}$.

We tested two 25-nt long probes each of D. acuminata and $D$. acuta and one of $D$. norvegica. Of the two probes targeting D. acuminata, DacumiD02 25 showed stronger signal intensity than the probe DacumiS01 25. We observed cross-reactions (false positive) for probe DacumiD02 25 with rDNA of $D$. acuta and D. fortii and for probe DacumiS01 25 with rDNA of $P$. rotundatum if the washing temperature was lower than $55^{\circ} \mathrm{C}$. Of the three probes targeting $D$. acuta, DacutaD02_25 showed the strongest signal intensity. positive signal. Probes without the suffix “ 25 ” are only 18-22 nt in length, but target the same region and taxon. For a summary, see Table 5 and for a full list of all probes on the MIDTAL array, see Supplementary Table S1

Probe DacutaS01_25 and the corresponding 18-nt probe Dacut showed no unspecific binding, but probe DacutaD02_25 was found to cross-react with $D$. fortii if the washing temperature was $55^{\circ} \mathrm{C}$ or lower.

One probe for $D$. norvegica (Dnorv) was modified for the microarray assay (DnorvS01_25), but its positive signal was untested because no cells or cultures of this species were available for us, but the probe did not hybridize to the DNA of D. acuta, D. acuminata, or D. fortii to produce a falsepositive reaction under high-stringency washing conditions (Figs 3 and S1a-d). It showed, however, a weak positive signal to $D$. tripos (but see above) and a false-positive signal for $P$. rotundatum, which has only one mismatch with this probe (Table 4). Here, a competitor probe matching $100 \%$ with $P$. rotundatum may be used to remove this target.

At the lower washing temperatures, there were several false positives (e.g., DacumiD02_25 and DacumiS01_25 in Fig. 3 and probes for Azadinum spinosum and Prymnesium spp., data not shown), but most of the false positives disappeared as the washing temperatures were increased (Fig. 3). The signal produced by each of the probes at an optimal washing temperature of $50{ }^{\circ} \mathrm{C}$ when hybridized to rDNA amplicon of the five species can be seen in Supplementary Fig. S1e.

The specificity of the probes on microarray generation 3 was tested with total RNA from cultures of $D$. acuminata and D. acuta at standard stringency conditions (hybridization temperature of $65^{\circ} \mathrm{C}$ and washing temperature of $50{ }^{\circ} \mathrm{C}$; data not shown; but for a summary, see Table 5). Here, the family-level probe DphyGS03 25 hybridized to RNA of both $D$. acuminata and D. acuta, whereas DphyexacutaFS01_25 did only hybridize to D. acuminata RNA and DphyFS02_25 to neither 
Table 5 Specificity of microarray probes tested against rDNA amplicons amplified from single cells (microarray generation 2) or total RNA extracted from cultures (microarray generation 3 )

\begin{tabular}{|c|c|c|c|c|c|c|c|}
\hline Probe Nucleic acid & $\begin{array}{l}\text { D. acuminata } \\
\text { rDNA }\end{array}$ & $\begin{array}{l}\text { D. acuta } \\
\text { rDNA }\end{array}$ & $\begin{array}{l}\text { D. fortii } \\
\text { rDNA }\end{array}$ & $\begin{array}{l}\text { D. tripos } \\
\text { rDNA }\end{array}$ & $\begin{array}{l}\text { P. rotundatum } \\
\text { rDNA }\end{array}$ & $\begin{array}{l}\text { D. acuminata } \\
\text { RNA }\end{array}$ & $\begin{array}{l}\text { D. acuta } \\
\text { RNA }\end{array}$ \\
\hline Dacum & $P$ & $\mathrm{~N}$ & $\mathrm{~N}$ & $\mathrm{~N}$ & $\mathrm{~N}$ & nd & nd \\
\hline DacumiD02_25 & $\mathrm{P}$ & $\mathbf{P}$ & $\mathbf{P}$ & $\mathrm{N}$ & $\mathrm{N}$ & $\mathrm{P}$ & $\mathrm{N}$ \\
\hline DacumiS01_25 & $\mathrm{P}$ & $\mathbf{P}$ & $\mathrm{N}$ & $\mathrm{N}$ & $\mathrm{N}(T \geq 55)$ & $\mathrm{P}$ & $\mathbf{P}$ \\
\hline Dacut & $\mathrm{N}$ & $\mathrm{P}$ & $\mathrm{N}$ & $\mathrm{N}$ & $\mathrm{N}$ & nd & nd \\
\hline DacutaD02_25 & $\mathrm{N}$ & $\mathrm{P}$ & $\mathbf{P}$ & $\mathrm{N}$ & $\mathrm{N}$ & $\mathrm{N}$ & $\mathrm{P}$ \\
\hline DacutaS01_25 & $\mathrm{N}$ & $\mathrm{P}$ & $\mathrm{N}$ & $\mathrm{N}$ & $\mathrm{N}$ & $\mathrm{N}$ & $\mathrm{P}$ \\
\hline DinoB_25 & $\mathrm{P}$ & $\mathrm{P}$ & $\mathrm{P}$ & $N$ & $\mathrm{P}(T=45)$ & $\mathrm{P}$ & $\mathrm{P}$ \\
\hline DinoE12_25 & $P$ & $\mathrm{P}$ & $\mathrm{P}$ & $N$ & $P$ & $\mathrm{P}$ & $\mathrm{P}$ \\
\hline Dnorv & $\mathrm{N}$ & $\mathrm{N}$ & $\mathrm{N}$ & $\mathrm{N}$ & $\mathrm{N}$ & nd & nd \\
\hline DnorvS01_25 & $\mathrm{N}$ & $\mathrm{N}$ & $\mathrm{N}$ & $\mathbf{P}$ (weak) & $\mathbf{P}$ & $\mathrm{N}$ & $\mathrm{N}$ \\
\hline DphyFL1 & $P$ & $P$ & $\mathrm{P}$ & P (weak) & $\mathrm{P}$ & nd & nd \\
\hline DphyFL2 & $\mathrm{P}$ & $\mathrm{P}$ & $\mathrm{P}$ & $\mathrm{P}$ & $\mathrm{P}$ & nd & nd \\
\hline DphyexacutaFS01_25 & nd & nd & nd & nd & nd & $\mathrm{P}$ & $N$ \\
\hline DphyFS02_25 & $\mathrm{P}$ & $\mathrm{P}$ & $\mathrm{P}$ & $\mathrm{P}$ (weak) & $\mathrm{P}$ & $N$ & $N$ \\
\hline DphyGD01 & $\mathrm{P}$ & $\mathrm{P}$ & $\mathrm{P}$ & $\mathrm{P}$ & $\mathrm{N}$ & nd & nd \\
\hline DphyGD01_25 & nd & nd & nd & nd & nd & $\mathrm{P}$ & $\mathrm{P}$ \\
\hline DphyGD02 & $\mathrm{P}$ & $\mathrm{P}$ & $\mathrm{P}$ & $\mathrm{P}$ & $\mathrm{N}(T \geq 55)$ & nd & nd \\
\hline DphyGD02_25 & nd & nd & nd & nd & nd & $N$ & $N$ \\
\hline DphyGL1 & $\mathrm{P}(T=40)$ & $\mathrm{P}(T=40)$ & $N$ & $N$ & $\mathrm{~N}$ & nd & nd \\
\hline DphyGL2 & $\mathrm{P}$ & $\mathrm{P}$ & $\mathrm{P}$ & $\mathrm{P}$ & $\mathrm{N}$ & nd & nd \\
\hline DphyGS01_25 & $N$ & $N$ & $N$ & $N$ & $\mathrm{~N}$ & $\mathrm{P}$ & $\mathrm{P}$ \\
\hline DphyGS02_25 & $\mathrm{P}$ & $\mathrm{P}$ & $\mathrm{P}$ & $\mathrm{P}$ & $\mathrm{N}$ & $\mathrm{P}$ & $\mathrm{P}$ \\
\hline DphyGS03_25 & $\mathrm{P}$ & $\mathrm{P}$ & $\mathrm{P}$ & $\mathrm{P}$ & $\mathrm{P}$ & $\mathrm{P}$ & $\mathrm{P}$ \\
\hline DphyGS04_25 & $\mathrm{P}$ & $\mathrm{P}$ & $\mathrm{P}$ & $\mathrm{P}$ & $\mathrm{N}$ & $\mathrm{P}$ & $\mathrm{P}$ \\
\hline ProtuS01_25 & nd & nd & nd & nd & nd & $\mathrm{N}$ & $\mathrm{N}$ \\
\hline
\end{tabular}

"P" rendered in bold denotes a false-positive signal and "N" rendered in italics denotes a false-negative signal at standard stringency conditions (e.g., $50{ }^{\circ} \mathrm{C}$ washing temperature)

$n d$ probe not present on this microarray, $P$ positive signal, $N$ negative signal $(\mathrm{S} / \mathrm{N}<2)$

D. acuminata nor D. acuta RNA (Table 5) in these tests. Of the genus-level probes, all except DphyGD02_25 hybridized to RNA of both species. Both probes for D. acuta (DacutaD02_25 and DacutaS01_25) were specific for $D$. acuta. We detected, however, cross-reactivity with probe DacumiS01_25 to D. acuta RNA. Unspecific binding was not observed with the probes for P. rotundatum or D. norvegica (ProtuS01_25 and DnorvS01_25; Table 5).

\section{Calibration curves for Dinophysis}

RNA samples from cultures of D. acuminata and D. acuta were hybridized on version 3 microarrays to construct two calibration curves (specific probe signal versus cell numbers for both species), as shown in Fig. 4, using the speciesspecific probes DacumiS01_25 and DacutaS01_25, respectively. We observed significant variation in the RNA amount per cell that could be caused by the physiological status of the cultures and, less likely, by the yield of RNA extraction (Blanco et al., submitted; Taylor et al., submitted). Lowest estimates for total RNA per cell were $0.023 \pm 0.001$ and $0.036 \pm 0.003 \mathrm{ng}$ for $D$. acuminata and D. acuta, respectively $(n=3)$. Maximum estimates of up to 0.120 and $0.240 \mathrm{ng}$ per cell of D. acuminata and D. acuta, respectively, were obtained. For further calculations of cell numbers from RNA, we assumed a mean cellular RNA content of 0.050 and $0.083 \mathrm{ng}$ per cell of D. acuminata and D. acuta, as mentioned previously. This assumption implies that a $2.4-$ to 2.9-fold divergence between cell numbers inferred from microarrays and cell counts needs to be accepted due to the observed range in cellular RNA contents. Based on the average RNA amount assayed in the calibration curves (which still fits the regression line), we estimated a minimum of 345 and 950 cells of D. acuminata and D. acuta, respectively, that would be detected by microarrays. However, fewer cells can be calculated below this cutoff as RNA levels as 

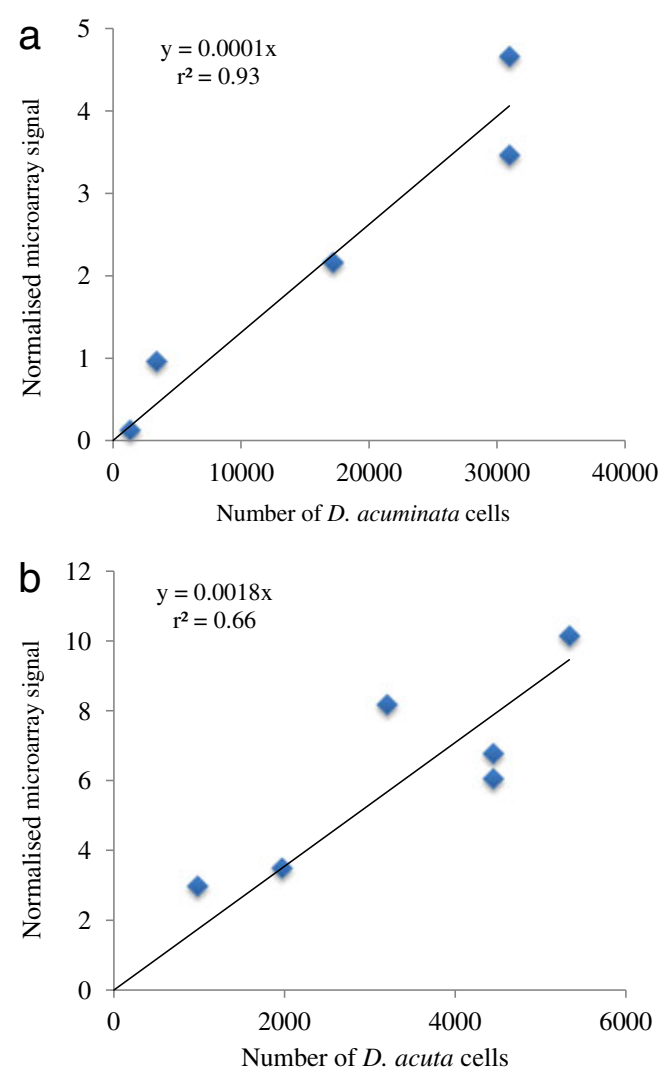

Fig. 4 Calibration curve: normalized microarray signal from the probes a DacumiS01_25 and b DacutaS01_25 as a function of number of cells of $D$. acuminata and $D$. acuta, respectively. Number of cells were estimated from the amount of RNA per cell as described in the "Material and methods" section

low as $10 \mathrm{ng}$ have rendered positive signals in the field, which would equate to $\sim 200$ and $\sim 120$ cells of $D$. acuminata and $D$. acuta, respectively.

\section{Microarray (generation 3) results with field samples}

Throughout the monitoring period at the Oslofjorden sampling site (OF2), microarray signals for Dinophysis spp. above the detection limit (signal to noise ratio $[\mathrm{S} / \mathrm{N}] \geq 2$ ) were observed all year round, except in August and November 2010 as well as February and April 2011 (Fig. 5a-c). As the sampling progressed from August 2010 to June 2011, the signals from the probes more closely matched the cell counts. In October 2010, as well as January-March, May, and June 2011, at least two cells of Dinophysis/Phalacroma were observed in the sedimented and counted samples $(=\mathrm{a}$ concentration estimate of 200 cells $\mathrm{L}^{-1}$ ) and the signal on the microarray was above the detection limit. In April 2011, one cell of D. norvegica (Fig. 5b) and one of P. rotundatum (not shown) were also observed, but microarray signals for this sample were below the detection limit. This observation may correspond to a loss in sensitivity in the microarray because of the presence of large quantities of nontarget species, notably a bloom of Chaetoceros spp. (Bacillariophyceae), although the ratio between concentrations of target and nontarget RNA has not been empirically tested to see if it affects hybridization and detection efficiency. No signals were observed in any of the samples for the probes DphyFS02_25, DphyGD02_25, DacutaD02_25, and ProtuS01_25, indicating that these probes are not sufficiently sensitive for the microarray to detect low quantities of Dinophysis RNA using the current MIDTAL protocol. In the case of $P$. rotundatum, a single cell (estimated concentration of 100 cells $\mathrm{L}^{-1}$ ) was detected on three occasions (August 2010 and April and May 2011) by cell counts, with no corresponding microarray signal (data not shown).

In the Oslofjorden OF2 field samples, D. acuminata and $D$. norvegica usually cooccurred, except from March to May 2011 when D. norvegica, but not D. acuminata, was observed. Probe signals for DnorvS01_25 were absent on all dates where $D$. norvegica occurred, except in March 2011, where there were both high microarray signals and cell counts (Fig. 5b). No cross-reactivity with the D. norvegica probe was ever observed in station P2 (Spain; see the succeeding paragraphs) where D. acuminata, but not $D$. norvegica, was present in cell counts. Thus, the D. norvegica probe appeared to be species-specific, but positive signals were obtained only at higher target concentrations $\left(900\right.$ cell L $\left.{ }^{-1}\right)$.

For D. acuminata, the signals followed the cell counts, except in March and May 2011, where no cells, but microarray signals were recorded (Fig. 5c). Furthermore, there was a high microarray signal in June, even though only two cells (estimated concentration of 200 cells $\mathrm{L}^{-1}$ ) were counted. This may indicate that the $D$. acuminata probe (DacumiS01_25) is not specific and cross-reacts with $D$. norvegica, although no cross-reactivity was detected during specificity tests if the washing temperature was maintained over $50^{\circ} \mathrm{C}$. Another explanation could be that $D$. acuminata was present in the large sample volume taken for the microarray ( $1 \mathrm{~L})$, but not present in the smaller volume taken for cell counts $(10 \mathrm{ml})$ on the dates when the microarray signal is present, but no cells were found during the cell counts.

At the monitoring site station P2 in Spain, Dinophysis cells were observed in cell counts in the period April-July 2010 , with $D$. acuminata as the dominant species. Field samples from this period hybridized with the microarray generation 3 are shown in Fig. 6. The higher group-level probes (Fig. 6a), although highly variable in $\mathrm{S} / \mathrm{N}$ ratio, followed the observed trends in Dinophysis spp. abundance by cell counts. The genus probe DphyGS02_25 and family probe DphyGS03 25 showed the highest signals and DphyGS01_25 the weakest signals. Based on the calibration 
Fig. 5 Microarray signals and cell counts from water samples collected in the period August 2010-June 2011 from Norway, Oslofjorden, station OF2. a Dinophysis spp. cell counts and signals from family-level or genus-level probes; b, c data

for $D$. norvegica and $D$. acuminata, respectively a

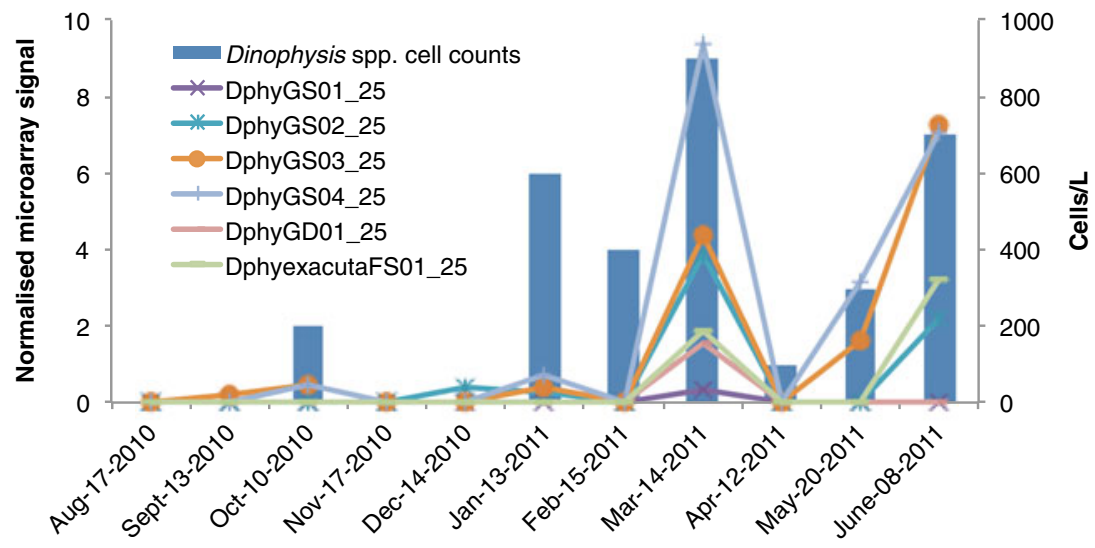

b
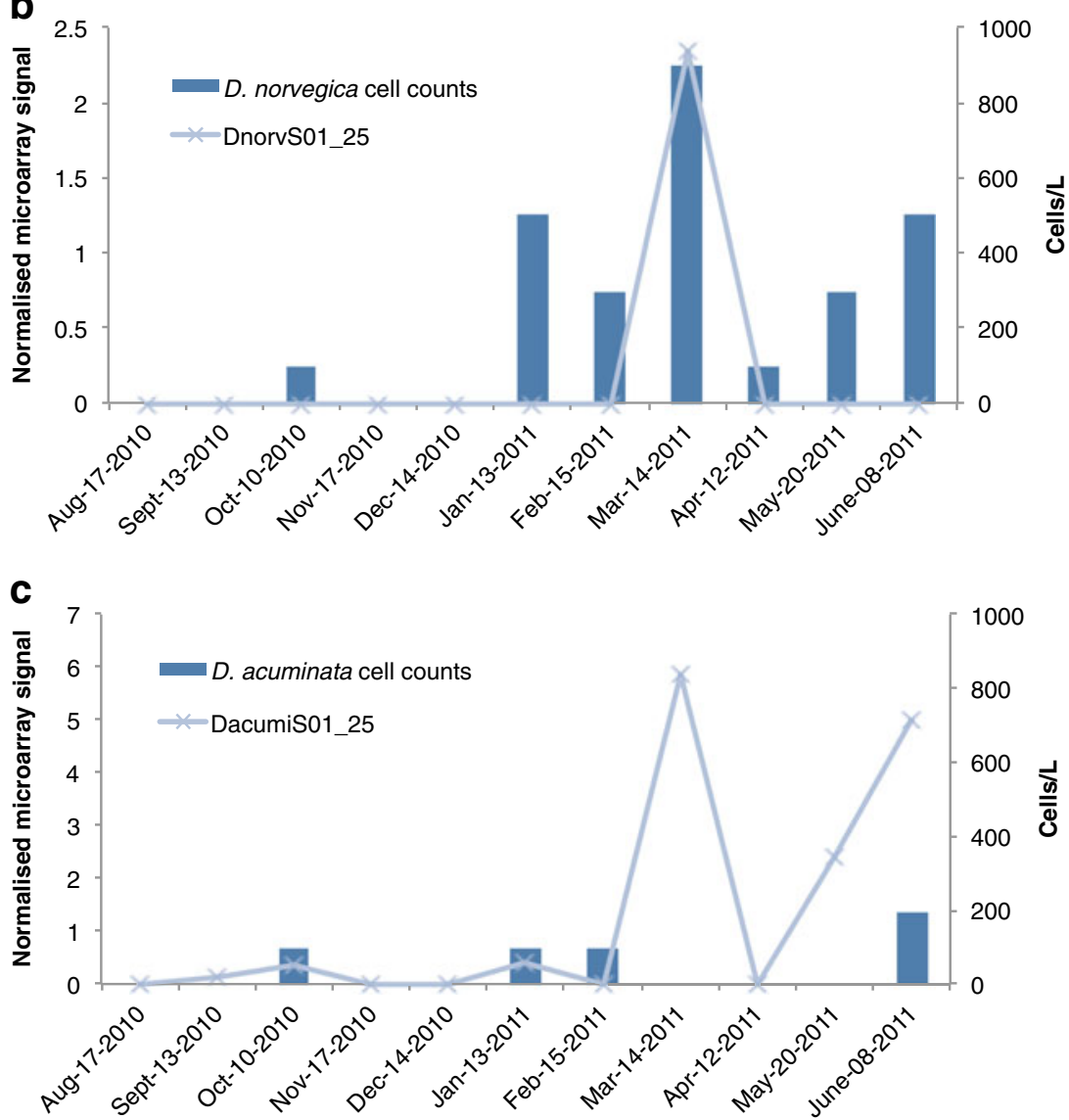

curve in Fig. 4 and the microarray signals of DacumiS01_25 in Fig. 6b, we inferred cell numbers for D. acuminata in the field. These were adjusted for the amount of RNA hybridized and the volume filtered. Cell numbers inferred from microarray signals were generally consistent with corresponding cell counts, although usually higher (Fig. 7), especially in July. Even if methodological factors cannot be ruled out, one of the most important reasons for these discrepancies could be the variable RNA contents per cell in Dinophysis, as observed in our data from cultures.

\section{Discussion}

This is the first description of molecular probes specific for members of Dinophysis and Phalacroma targeting the nuclear SSU rRNA gene. The main advantages of using ribosomal RNA as a marker are the large available database of rDNA sequences of target and nontarget taxa to design specific probes. Several studies have used the nuclear LSU rRNA gene as target for probe development for Dinophysis species, which has the same advantage with large amounts 
Fig. 6 Microarray signals and cell counts from water samples collected in the period AprilJuly 2010 from Spain, Ría de Pontevedra, station P2. a Dinophysis spp. cell counts and signals from probes at family, genus, or species level; b data for D. acuminata

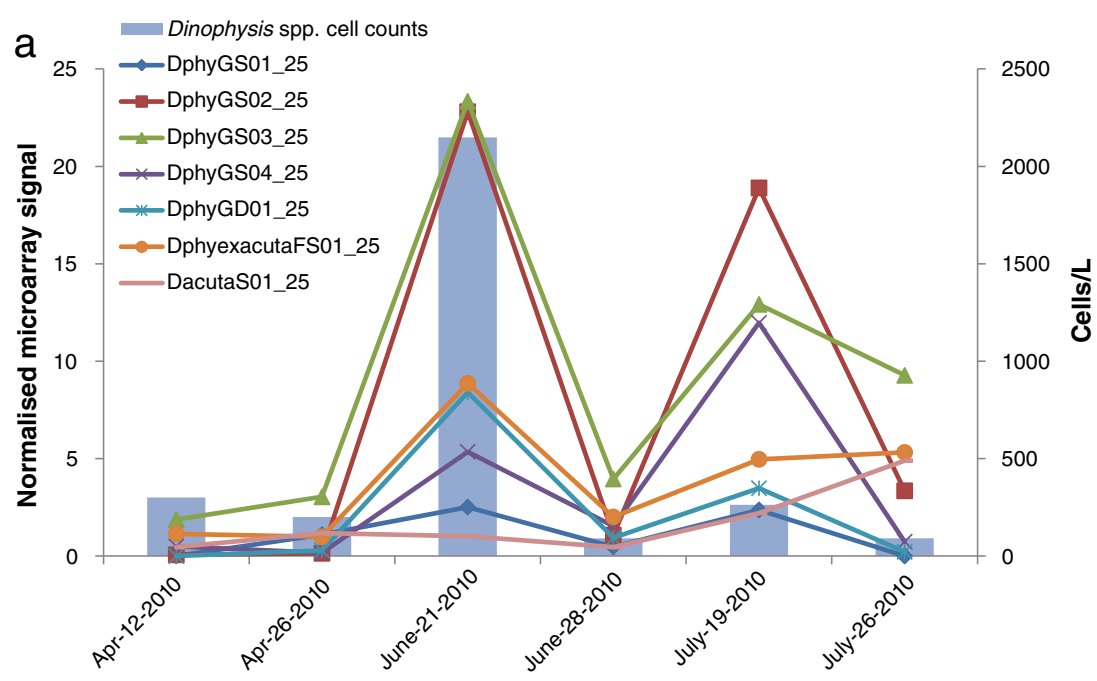

b

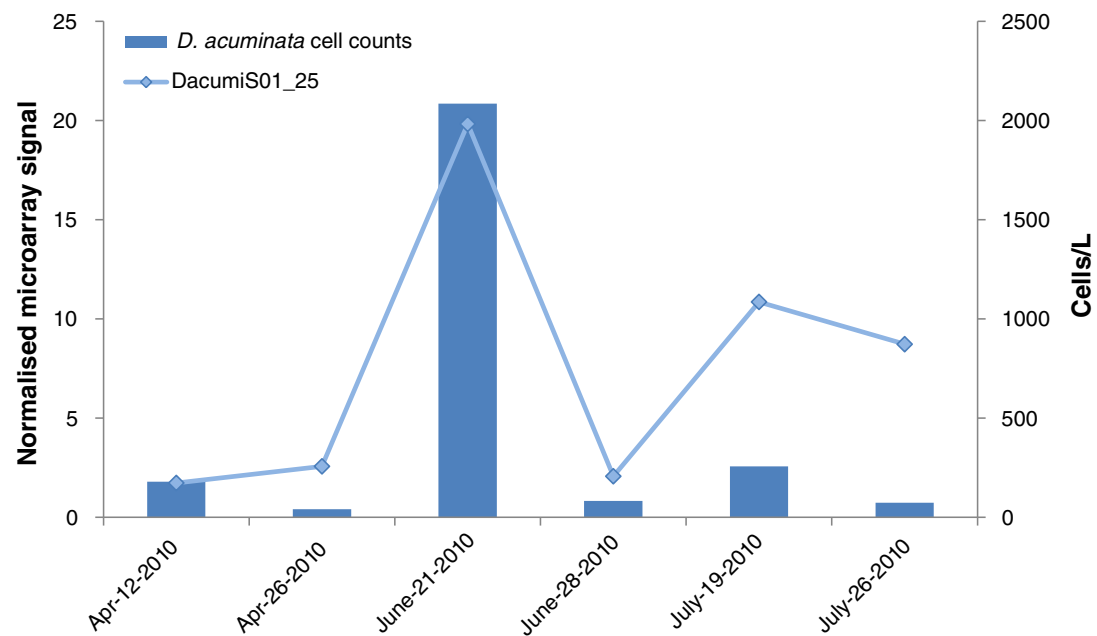

of RNA in the cells, but the database of available LSU rDNA sequences of cultured taxa (also partial sequences embracing the D1-D2 region only) is much smaller, especially for nontarget cooccurring taxa. Guillou et al. (2002) developed two PCR primers to amplify the LSU rDNA region of D. acuminata and D. saccula. We adapted (shifted and elongated) these LSU probes for use with microarrays and used these for the MIDTAL microarray in this study. Their specificity was tested and found to be less specific as compared to the original study. Hart et al. (2007) developed Dinophysis clade-specific primers for amplification of partial LSU rDNA (the D1-D2 region) to avoid cloning. Kavanagh et al. (2010) described a quantitative real-time PCR assay with primers and hybridization probes specific for $D$. acuminata and D. acuta targeting LSU rDNA. Takahashi et al. (2005) described FISH probes specific for Dinophysis spp. targeting the plastid-encoded SSU rDNA and $r b c \mathrm{~L}$. The present study provides additional probes for more Dinophysis and Phalacroma taxa at various taxonomic levels, which enables the use of several probes in a hierarchical manner suitable for the microarray platform. In this way, cross-reactivity with nontarget RNA can be filtered with software, such as PhylochipAnalyzer (Metfies et al. 2008) or GPR-Analyzer, which has been developed for analysis of the MIDTAL microarray (Dittami and Edvardsen 2013) and used in this study. All of these probes and primers contribute in different ways to a more precise and rapid monitoring of toxic species within this widespread dinoflagellate group and also have the possibility for a more automated detection. They can also be modified for and applied in other types of assays (e.g., FISH, QPCR, NGS). A comparison of the time and cost for various detection methods and advantages and disadvantages was provided by Dittami et al. (2013a).

The probes that were developed in this study were tested for their specificity by dot blot hybridization against rDNA fragments of 17 target and nontarget microalgal taxa and were found to be specific at hybridization temperatures between 54 and $65{ }^{\circ} \mathrm{C}$ and probe concentrations of $0.01-$ $0.2 \mathrm{ppb}$, depending on the probe. All eight probes were suitable for the detection of SSU rDNA amplicons from 


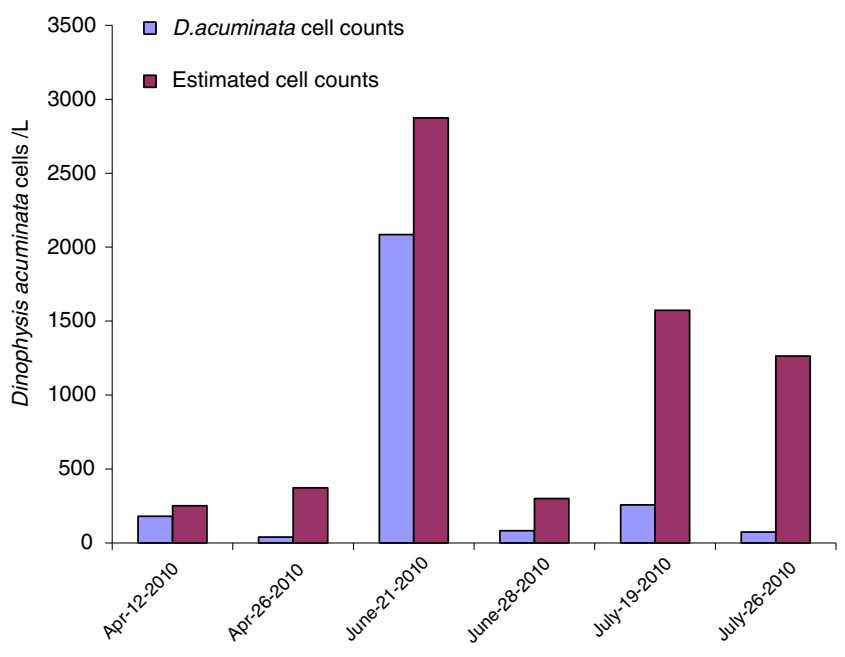

Fig. 7 Comparison between inferred cell numbers by the microarray probe DacumiS01_25 (0.5 L filtered sample volume from concentrated field samples; see the "Material and methods" section) and microscopic cell counts ( $100 \mathrm{ml}$ settled volume) for $D$. acuminata. Samples were collected in the period April-July 2010 from Spain, Ría de Pontevedra, station P2 and correspond to the data displayed in Fig. 6b

algae of the genera Dinophysis and/or Phalacroma at possibly family, genus, or species level in dot blot assays. The probes were designed from a database of global isolates and thus can be universally applied.

The format of dot blot hybridization and microarrays allows a large number of probes or environmental samples to be tested in parallel, either by spotting samples onto a membrane/slide and hybridising with labeled probes, as was done with the dot blots in this paper, or vice versa, like in the microarray experiments. Whereas they lack the high throughput and automatization capabilities of microarrays, DNA dot blots can still be useful for testing probe specificity or analyzing environmental samples. DNA dot blots have been applied, for example, to study Bolidophyceae in the Pacific and Mediterranean Sea (Guillou et al. 1999) and prymnesiophytes in the Pacific (Moon-van der Staay et al. 2000), as well as the abundance of a variety of eukaryotic picoplankton classes in the Gulf of Naples (McDonald et al. 2007). Their advantage over microarrays lie in the significantly lower costs for small-scale experiments that do not require investment in expensive microarray spotter and reader. However, microarrays allow for an almost unlimited number of probes or samples to be analyzed in one assay. This feature and the capability for automation, something dot blots are lacking, are the big advantages of microarrays, especially for the application in largescale routine monitoring programs for HABs. We believe that microarrays presently constitute a good complement to cell counts and, in the long run, may replace cell counts, but only after improving the technique and extensive validation.
The developed dot blot SSU and previously published LSU rDNA probes (Guillou et al. 2002) were modified for the microarray assay. The specificity of the microarray probes was tested in the microarray platform. The probes were found to hybridize to the target and did not, as a rule, cross-react with the nontarget rDNA or RNA tested (but see Table 5). Only one genus-level probe (DphyGD02_25) did not work in the microarray platform generation 3 when tested with RNA. For some probes, a strong signal can be obtained with the PCR products, but not the total RNA, even though it can be fragmented to shorter pieces (Metfies and Medlin 2008). Complications with the secondary structure and probe access is a possible explanation for this. Calibration curves for RNA versus cell numbers were obtained for $D$. acuminata and $D$. acuta to make the microarray semiquantitative. Detection limits were determined for both species that correspond to an $\mathrm{S} / \mathrm{N}$ ratio of 2, although cell counts can be inferred at lower detection limits if needed.

The microarray assay was applied to field samples from Norway and Spain, and microarray signals were compared to cell counts from the same samples. This was possible because of the large amounts of RNA in the cell that can give a strong hybridization signal without including a PCR amplification step, thus allowing the quantification of rRNA in the samples. When comparing our microarray data directly with cell numbers, however, the observed up to sixfold variation in the cellular RNA contents of Dinophysis needs to be considered as a source of variability. Because cellular RNA content is generally correlated with growth rate and cell size (for examples in other organisms, see Fegatella et al. 1998 or Dittami and Edvardsen 2012), our array is likely to overestimate cell concentrations for larger, growing cells and to underestimate those of small, dormant, or dying cells. As a consequence, microarray signals correlated well with cell counts on some dates and not on others. However, our microarray is designed to be used as an early warning system so we would be detecting cells that are not dormant or dying. In addition to differences in RNA contents, there may be an effect of the extraction efficiencies on the dates when they were not well-correlated and an effect of filtering a larger volume for RNA extraction as compared to volumes taken for cell counts. Moreover, if there is a poor labelling efficiency or a poor quality of RNA, then the microarray signal can be compromised. Finally, even though most of our probes were shown to be specific in culture experiments, we observed some indications for possible nonspecific binding in field and culture samples for the probe "DacumiS01 25," which cross-hybridizes with $D$. acuta and possibly also $D$. norvegica. Further tests with $D$. norvegica cultures will be necessary to confirm this, and additional optimization of this probe or the hybridization protocol may be required before reliable destinction between $D$. norvegica/D. acuta and $D$. acuminata can be achieved. 
Much effort was devoted to performing an efficient extraction of Dinophysis relative to other dinoflagellates using a standard extraction protocol for all species. Dinophysis proved to be highly resistant to cell rupture, especially in the toxin analysis (McNamee et al. 2013) where the strong solvent TRI Reagent is not used. In conclusion, despite the methodological issues reported in this study, we found that the microarray approach was useful for the semiquantitative detection of Dinophysis spp.

Acknowledgments MIDTAL is a project under the EU's 7th Framework Program (FP7-ENV-2007-1-MIDTAL-201724) and provided funding for all but RG during this work. The Norwegian Research Council provided funding to BE through the project MOLHAS (140286/120) and TOXALGAE (196702/S40). RG was funded in part by the Alfred Wegener Institute for Polar and Marine Research, Bremerhaven, Germany. Vladyslava Hostyeva and Wenche Eikrem are thanked for the cell counts at the Oslofjorden station OF2. Two anonymous reviewers are thanked for the valuable comments to an earlier version that improved the manuscript considerably.

Open Access This article is distributed under the terms of the Creative Commons Attribution License which permits any use, distribution, and reproduction in any medium, provided the original author(s) and the source are credited.

\section{References}

Anderson DM (1995) Identification of harmful algal species using molecular probes:an emerging perspective. In: Lassus P, Arzul G, Erard-Le Denn E, Gentien P, Marcaillou-Le Baut C (eds) Harmful marine algal blooms. Lavoisier Intercept Ltd, Paris, pp $3-13$

Andersen P, Hald B, Emsholm H (1996) Toxicity of Dinophysis acuminata in Danish coastal waters. In: Yasumoto T, Oshima Y, Fukuyo Y (eds) Harmful and toxic algal blooms. Harmful and Toxic Algal Blooms, Intergovernmental Oceanographic Commission of UNESCO, Sendai, pp 281-283

Aune T, Strand Ø, Aase B, Weidemann J, Dahl E, Hovgaard P (1996) The Sognefjord in Norway, a possible location for mussel farming? In: Yasumoto T, Oshima Y, Fukuyo Y (eds) Harmful and toxic algal blooms. Intergovernmental Oceanographic Commission of UNESCO, Sendai, pp 73-75

Blanco J, Álvarez G, Uribe E (2006) Identification of pectenotoxins in plankton, filter-feeders, and isolated cells of a Dinophysis acuminata with an atypical toxin profile, from Chile. Toxicon 49:710 716

Blanco J, Moroño A, Pazos Y, Maneiro J, Mariño J (1998) Trends and variations of the abundance of main PSP and DSP producing species in the Galician Rías: environmental and biological influences. In: Reguera B, Fernández ML BJ, Wyatt T (eds) Harmful algae. Xunta de Galicia and Intergovernmental Oceanographic Commission of UNESCO, Santiago de Compostela, pp 204-207

Campbell L, Olson RJ, Sosik HM, Abraham A, Henrichs DW, Hyatt CJ, Buskey EJ (2010) First harmful Dinophysis (Dinophyceae, Dinophysiales) bloom in the U.S. is revealed by automated imaging flow cytometry. J Phycol 46:66-75

Dahl E, Aune T, Aase B (1996) Reddish water due to mass occurrence of Dinophysis spp. 1996. In: Yasumoto T, Oshima Y, Fukuyo Y (eds) Harmful and toxic algal blooms. Intergovernmental Oceanographic Commission of UNESCO, Sendai, pp 265-267
Dahl E, Johannessen T (2001) Relationship between occurrence of Dinophysis species (Dinophyceae) and shellfish toxicity. Phycologia 40:223-227

Delgado M, Garcés E, Camp J (1996) Growth and behaviour of Dinophysis sacculus from NW Mediterranean Sea. In: Yasumoto Y, Oshima Y, Fukuyo Y (eds) Harmful and toxic algal blooms. Intergovernmental Oceanographic Commission of UNESCO, Sendai, pp 261-264

Dereeper A, Guignon V, Blanc G, Audic S, Buffet S, Chevenet F, Dufayard J-F, Guindon S, Lefort V, Lescot M, Claverie J-M, Gascuel O (2008) Phylogeny.fr: robust phylogenetic analysis for the non-specialist. Nucleic Acids Res 36(Web Server Issue): W465-W469

Dittami SM, Riisberg I, Edvardsen B (2013a) Molecular probes for the detection and identification of ichthyotoxic marine flagellates of the genus Pseudochattonella (Dictyochophyceae, Heterokonta). Env Sci Poll Res (this volume)

Dittami SM, Edvardsen B (2013) GPR-Analyzer: a simple tool for quantitative analysis of hierarchical multispecies microarrays. Env Sci Poll Res (this volume)

Dittami SM, Edvardsen B (2012) Culture conditions influence cellular RNA content in ichthyotoxic flagellates of the genus Pseudochattonella (Dictyochophyceae). J Phycol 48:1050-1055

Dittami SM, Hostyeva H, Egge ES, Kegel JU, Eikrem W, Edvardsen B (2013b) Seasonal dynamics of harmful algae in outer Oslofjorden monitored by microarray, qPCR, and microscopy. Env Sci Poll Res (this volume)

Edvardsen B, Shalchian-Tabrizi K, Jakobsen KS, Medlin LK, Dahl E, Brubak S, Paasche E (2003) Genetic variability and molecular phylogeny of Dinophysis species (Dinophyceae) from Norwegian waters inferred from single cell analyses of rDNA. J Phycol 39:395-408

Eller G, Töbe K, Medlin LK (2007) Hierarchical probes at various taxonomic levels in the Haptophyta and a new division level probe for the Heterokonta. J Plankton Res 29:629-640

Escalera L, Reguera B (2008) Planozygote division and other observations on the sexual cycle of several species of Dinophysis (Dinophyceae, Dinophysiales). J Phycol 44:1425-1436

Fegatella F, Lim J, Kjelleberg S, Cavicchioli R (1998) Implications of rRNA operon copy number and ribosome content in the marine oligotrophic ultramicrobacterium Sphingomonas sp. strain RB2256. Appl Envir Microbiol 64:4433-4438

Fernández ML, Reguera B, González-Gil S, Míguez A (2006) Pectenotoxin-2 in single cell isolates of Dinophysis caudata and Dinophysis acuta from the Galician Rías (NW Spain). Toxicon 48:477-490

Fernández ML, Reguera B, Ramilo I, Martínez A (2001) Toxin content of Dinophysis acuminata, D. acuta and D. caudata from the Galician Rías Baixas. In: Hallegraeff GM, Blackburn SI, Bolch CJ, Lewis RJ (eds) Harmful algal blooms. Intergovernmental Oceanographic Commission of UNESCO, Paris, pp 360-363

Fernández-Puente P, Fidalgo-Sáez MJ, Hamilton B, Furey A, James KJ (2004) Studies of polyether toxins in the marine phytoplankton, Dinophysis acuta, in Ireland using multiple tandem mass spectrometry. Toxicon 44:919-926

Giacobbe MG, Penna A, Ceredi A, Milandri A, Poletti R, Yang X (2000) Toxicity and ribosomal DNA of the dinoflagellate Dinophysis sacculus (Dinophyta). Phycologia 39:177-182

Godhe A, Svensson S, Rehnstam-Holm A-S (2002) Oceanographic settings explain fluctuations in Dinophysis spp. and concentrations of diarrhetic shellfish toxin in the plankton community within a mussel farm area on the Swedish west coast. Mar Ecol Prog Ser 240:71-83

Godhe A, Cusack C, Pedersen J, Andersen P, Anderson D, Bresnan E, Cembella A, Dahl E, Diercks S, Elbrächter M, Edler L, Galuzzi L, 
Gescher C, Gladstone M, Karlson B, Kulis D, LeGresley M, Lindahl O, Marin R, McDermott G, Medlin L, Naustvoll L-J, Penna A, Töbe K (2007) Intercalibration of new and classic techniques for identification of Alexandrium fundyense and estimation of its cell densities. Harmful Algae 6:56-72

González-Gil S, Pizarro G, Paz B, Velo-Suárez L, Reguera B (2011) Considerations on the toxigenic nature and prey sources of Phalacroma rotundatum. Aquat Microb Ecol 64:197-203

Groben R, Doucette GJ, Kopp M, Kodama M, Amann R, Medlin LK (2000) 16S rRNA targeted probes for the identification of bacterial strains isolated from cultures of the toxic dinoflagellate Alexandrium tamarense. Microb Ecol 39:186-196

Groben R, John U, Eller G, Lange M, Medlin LK (2004) Using fluorescently-labelled rRNA probes for hierarchical estimation of phytoplankton diversity - a mini-review. Nova Hedwigia 79:313-320

Guillard RRL, Hargraves PE (1993) Stichochrysis immobilis is a diatom, not a chrysophyte. Phycologia 32:234-236

Guillou L, Moon-van der Staay SY, Claustre H, Partensky F, Vaulot D (1999) Diversity and abundance of Bolidophyceae (Heterokonta) in two oceanic regions. Appl Environ Microbiol 65:4528-4536

Guillou L, Nézan E, Cueff V, Erard-Le Denn E, Cambon-Bonavita M-A, Gentien P, Barbier G (2002) Genetic diversity and molecular detection of three toxic dinoflagellate genera (Alexandrium, Dinophysis, and Karenia) from French coasts. Protist 153:223-238

Hackett JD, Tong M, Kulis DM, Fux E, Hess P, Bire R, Anderson DM (2009) DSP toxin production de novo in cultures of Dinophysis acuminata (Dinophyceae) from North America. Harmful Algae 8:873-879

Hart MC, Green DH, Bresnan E, Bolch CJ (2007) Large subunit ribosomal RNA gene variation and sequence heterogeneity of Dinophysis (Dinophyceae) species from Scottish coastal waters. Harmful Algae 6:271-287

Hasle GR (1978) The inverted microscope method. In: Sournia A (ed) Phytoplankton manual. UNESCO, Paris, pp 88-96

Jackson D, Silke J (1995) Dinophysis spp. and the occurrence of diarrhetic shellfish poisons in Ireland. In: Lassus P, Arzul G, Erard-Le Denn E, Gentien P, Marcaillou-Le Baut C (eds) Harmful marine algal blooms. Lavoisier Intercept Ltd, Paris, pp 789-794

Johansson N, Graneli E, Yasumoto T, Carlsson P, Legrand C (1996) Toxin production by Dinophysis acuminata and D. acuta cells grown under nutrient sufficient and deficient conditions. In: Yasumoto Y, Oshima Y, Fukuyo Y (eds) Harmful and toxic algal blooms. Intergovernmental Oceanographic Commission of UNESCO, Sendai, pp 277-280

John U, Medlin LK, Groben R (2005) Development of specific rRNA probes to distinguish between geographic clades of the Alexandrium tamarense species complex. J Plankton Res 27:199-204. doi:10.1093/plankt/fbh160

John U, Cembella AD, Hummert C, Elbrächter M, Groben R, Medlin LK (2003) Discrimination of the toxigenic dinoflagellates Alexandrium tamarense and Alexandrium ostenfeldii in co-occurring natural populations from Scottish coastal waters. Eur J Phycol 38:25-40

Johnsen TM, Lømsland ER (2012) Observations of Dinophysis tripos in Norwegian coastal waters. In: Pagou P, Hallegraeff G (eds) Proceedings of the 14th International Conference on Harmful Algae. International Society for the Study of Harmful Algae and Intergovernmental Oceanographic Commission of UNESCO, Crete, pp 58-59

Jørgensen K, Andersen P (2007) Relation between the concentration of Dinophysis acuminata and diarrheic shellfish poisoning toxins in blue mussels (Mytilus edulis) during a toxic episode in the Limfjord (Denmark), 2006. J Shellfish Res 26:1081-1087
Katoh K, Kuma K, Toh H, Miyata T (2005) MAFFT version 5: improvement in accuracy of multiple sequence alignment. Nucleic Acids Res 33:511-518

Kavanagh S, Brennan C, O'Connor LO, Moran S, Salas R, Lyons J, Maher M (2010) Real-time PCR detection of Dinophysis species in Irish coastal waters. Mar Biotech 12:534-542

Kegel J, Amo A, Medlin LK (2013) Introduction to project MIDTAL: its methods and samples from Arcachon Bay, France. Env Sci Poll Res (this volume)

Lee JS, Igarashi T, Fraga S, Dahl E, Hovgaard P, Yasumoto T (1989) Determination of diarrhetic shellfish toxins in various dinoflagellate species. J Appl Phycol 1:147-152

Lewis J, Medlin LK, Raine R (2012) MIDTAL (Microarrays for the Detection of Toxic Algae):a protocol for a successful microarray hybridisation and analysis. Koeltz Scientific Books, Königstein

Lim EL, Amaral LA, Caron DA, Delong EF (1993) Application of rRNA-based probes for observing marine nanoplanktonic protists. Appl Environ Microbiol 59:1647-1655

Lindahl O, Lundve B, Johansen M (2007) Toxicity of Dinophysis spp. in relation to population density and environmental conditions on the Swedish west coast. Harmful Algae 6:218-213

Ludwig W, Strunk O, Westram R, Richter L, Meier H, Yadhukumar BA, Lai T, Steppi S, Jobb G, Förster W, Brettske I, Gerber S, Ginhart AW, Gross O, Grumann S, Hermann S, Jost R, König A, Liss T, Lüssmann R, May M, Nonhoff B, Reichel B, Strehlow R, Stamatakis A, Stuckmann N, Vilbig A, Lenke M, Ludwig T, Bode A, Schleifer K-H (2004) ARB:a software environment for sequence data. Nuc Acids Res 32:1363-1371. doi:10.1093/nar/ gkh293

Marasigan AN, Sato S, Fukuyo Y, Kodama M (2001) Accumulation of a high level of diarrhetic shellfish toxins in the green mussel Perna viridis during a bloom of Dinophysis caudata and Dinophysis miles in Saipan Bay, Panay Island, the Philippines. Fish Sci 67:994-999

Marcaillou-Le Baut C, Mondeguer F, Gentien P (2005) Contribution to toxicity assessment of Dinophysis acuminata (Dinophyceae). J Appl Phycol 17:155-160

Masselin P, Lassus P, Bardouil M (1992) High performance liquid chromatography analysis of diarrhetic toxins in Dinophysis spp. from the French coast. J Appl Phycol 4:385-389

McDonald SM, Sarno D, Scanlan DJ, Zingone A (2007) Genetic diversity of eukaryotic ultraplankton in the Gulf of Naples during an annual cycle. Aq Micro Ecol 50:75-89

McNamee S, Campbell K, Elliot C (2013) Multi biotoxin surface plasmon resonance method for marine biotoxins in algal and seawater samples. Env. Scien Poll Res (this volume)

Medlin LK, Elwood HJ, Stickel S, Sogin ML (1988) The characterization of enzymatically amplified eukaryotic 16S-like rRNA-coding regions. Gene 71:491-499

Metfies K, Borsutzki P, Gescher C, Medlin LK, Frickenhaus S (2008) PhylochipAnalyser - a program for analysing hierarchical probe sets. Mol Ecol Res 8:99-102

Metfies K, Medlin LK (2008) Feasibility of transferring fluorescent in situ hybridization probes to an 18S rRNA gene phylochip and mapping og signal intensities. Appl Environ Microbiol 74:2814-2821

Miles CO, Wilkins AL, Samdal IA, Sandvik M, Petersen D, Quilliam MA, Naustvoll LJ, Jensen DJ, Cooney JM (2004) A novel pectenotoxin, PTX-12, in Dinophysis spp. and shellfish from Norway. Chem Res Toxicol 17:1423-1433

Miller PE, Scholin CA (1996) Identification of cultured Pseudo-nitzschia (Bacillariophyceae) using species specific LSU rRNA targeted fluorescent probes. J Phycol 32:646-655

Moestrup Ø, Akselman R, Cronberg G, Elbraechter M, Fraga S, Halim Y, Hansen G, Hoppenrath M, Larsen J, Lundholm N, Nguyen LN, Zingone A (eds) (2009 onwards). IOC-UNESCO 
taxonomic reference list of harmful micro algae. Available at http:// www.marinespecies.org/HAB. Accessed on 15 October 2012

Moon-van der Staay SY, van der Staay GWM, Guillou L, Vaulot D, Claustre H, Medlin LK (2000) Abundance and diversity of prymnesiophytes in the picoplankton community from the equatorial Pacific ocean inferred from 18S rDNA sequences. Limnol Oceanogr 45:98-109

Pizarro G, Escalera L, González-Gil S, Franco JM, Reguera B (2008a) Growth, behaviour and cell toxin quota of Dinophysis acuta Ehrenberg during a daily cycle. Mar Ecol Prog Ser 353:89-105

Pizarro G, Paz B, Franco JM, Suzuki T, Reguera B (2008b) First detection of Pectenotoxin-11 and confirmation of OA-D8 diolester in Dinophysis acuta from European waters by LC-MS/MS. Toxicon 52:889-896

Pizarro G, Paz B, González-Gil S, Franco JM, Reguera B (2009) Seasonal variability of lipophilic toxins during a Dinophysis acuta bloom in Western Iberia: differences between picked cells and plankton concentrates. Harmful Algae 8:926-937

Pruesse E, Quast C, Knittel K, Fuchs B, Ludwig W, Peplies JO, Glöckner FO (2007) SILVA: a comprehensive online resource for quality checked and aligned ribosomal RNA sequence data compatible with ARB. Nucl Acids Res 35:7188-7196

Raho N, Pizarro G, Escalera L, Reguera B, Marín I (2008) Morphology, toxin composition and molecular analysis of Dinophysis ovum Schütt, a dinoflagellate of the "Dinophysis acuminata complex". Harmful Algae 7:839-848

Reguera B, González-Gil S (2001) Small cell and intermediate cell formation in species of Dinophysis (Dinophyceae, Dinophysiales). J Phycol 37:318-333

Reguera B, Rodríguez F, Blanco J (2012a) Harmful algae blooms and food safety: physiological and environmental factors affecting toxin production and their accumulation in shellfish. In: Cabado AG, Vieites JM (eds) New trends in marine and freshwater toxins: food safety concerns. Nova Science Publishers, Inc, New York, pp 53-89

Reguera B, Velo-Suárez L, Raine R, Park MG (2012b) Harmful Dinophysis species: a review. Harmful Algae 14:87-106

Rodríguez F, Escalera L, Reguera B, Rial P, Riobó P, Silva TJ (2012) Morphological variability, toxinology and genetics of the dinoflagellate Dinophysis tripos (Dinophysiaceae, Dinophysiales). Harmful Algae 13:26-33

Sato S, Koike K, Kodama M (1996) Seasonal variation of okadaic acid and dinophysistoxin-1 in Dinophysis spp. in association with the toxicity of scallop. In: Yasumoto Y, Oshima Y, Fukuyo Y (eds) Harmful and toxic algal blooms. Intergovernmental Oceanographic Commission of UNESCO, Sendai, pp 285-288
Scholin C, Miller P, Buck K, Chavez F, Harris P, Haydock P, Howard J, Cangelosi G (1997) Detection and quantification of Pseudo-nitzschia australis in cultured and natural populations using LSU rRNA-targeted probes. Limnol Oceanogr 42:12651272

Simon N, Brenner J, Edvardsen B, Medlin LK (1997) The identification of Chrysochromulina and Prymnesium species (Haptophyta, Prymnesiophyceae) using fluorescent or chemiluminescent oligonucleotide probes: a means of improving studies on toxic algae. Eur J Phycol 32:393-401

Solum I (1962) The taxonomy of Dinophysis populations in Norwegian waters in view of biometric observations. Nytt Mag Bot 10:533

Sournia A, Chrétiennot-Dinet M-J, Ricard M (1991) Marine phytoplankton: how many species in the world ocean? J Plankton Res 13:10931099

Sournia A (1995) Red-tides and toxic marine phytoplankton of the world ocean: an inquiry into biodiversity. In: Lassus P, Arzul G, Erard-Le Denn E, Gentien P, Marcaillou-Le Baut C (eds) Harmful marine algal blooms. Lavoisier Ltd, Nantes, pp 103-112

Suzuki T, Miyazono A, Baba K, Sugawara R, Kamiyama T (2009) LCMS/MS analysis of okadaic acid analogues and other lipophilic toxins in single-cell isolates of several Dinophysis species collected in Hokkaido, Japan. Harmful Algae 8:233-238

Takahashi Y, Takishita K, Koike K, Maruyama T, Nakayama T, Kobiyama A, Ogata T (2005) Development of molecular probes for Dinophysis (Dinophyceae) plastid: a tool to predict blooming and explore plastid origin. Mar Biotechnol 7:95-103. doi:10.1007/ s10126-004-0482-5

Throndsen J (1978) Preservation and storage. In: Sournia A (ed) Phytoplankton manual. UNESCO, Paris, pp 69-74

Tong M, Kulis DM, Fux E, Smith JL, Hess P, Zhou QX, Anderson DM (2011) The effects of growth phase and light intensity on toxin production by Dinophysis acuminata from the northeastern United States. Harmful Algae 10:254-264

Utermöhl H (1958) Zur Vervollkommnung der quantitativen Phytoplankton-Methodik. Mitt Int Ver theor angew Limnol 9:1-38

Vale P, Botelho MJ, Rodrigues SM, Gomes SS, Sampayo MAM (2008) Two decades of marine biotoxin monitoring in bivalves from Portugal (1986-2006): a review of exposure assessment. Harmful Algae 7:11-25

Zingone A, Montresor M, Marino D (1998) Morphological variability of the potentially toxic dinoflagellate Dinophysis sacculus (Dinophyceae) and its taxonomic relationships with $D$. pavillardii and D. acuminata. Eur J Phycol 33:259-273 